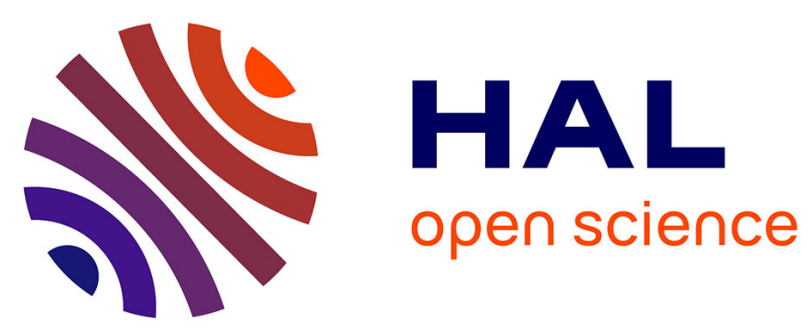

\title{
Linking thermochronological data to transient geodynamic regimes; new insights from kinematic modeling and Monte Carlo sampling of thermal boundary conditions
}

Nassif Francisco Sanchez, Kerry Gallagher, Miguel Ezpeleta, Gilda Collo, Federico Davila, Andres Mora

\section{To cite this version:}

Nassif Francisco Sanchez, Kerry Gallagher, Miguel Ezpeleta, Gilda Collo, Federico Davila, et al.. Linking thermochronological data to transient geodynamic regimes; new insights from kinematic modeling and Monte Carlo sampling of thermal boundary conditions. Journal of South American Earth Sciences, 2021, 105, pp.103018. 10.1016/j.jsames.2020.103018 . insu-03011247

\section{HAL Id: insu-03011247 \\ https://hal-insu.archives-ouvertes.fr/insu-03011247}

Submitted on 18 Nov 2020

HAL is a multi-disciplinary open access archive for the deposit and dissemination of scientific research documents, whether they are published or not. The documents may come from teaching and research institutions in France or abroad, or from public or private research centers.
L'archive ouverte pluridisciplinaire HAL, est destinée au dépôt et à la diffusion de documents scientifiques de niveau recherche, publiés ou non, émanant des établissements d'enseignement et de recherche français ou étrangers, des laboratoires publics ou privés. 


\section{Journal Pre-proof}

Linking thermochronological data to transient geodynamic regimes; new insights from kinematic modeling and Monte Carlo sampling of thermal boundary conditions

Sanchez Nassif Francisco, Gallagher Kerry, Ezpeleta Miguel, Collo Gilda, Davila Federico, Mora Andres

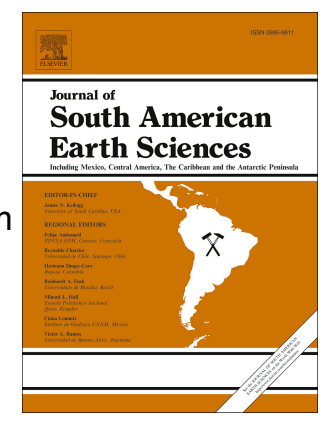

PII: S0895-9811(20)30561-7

DOI: https://doi.org/10.1016/j.jsames.2020.103018

Reference: $\quad$ SAMES 103018

To appear in: Journal of South American Earth Sciences

Received Date: 29 May 2020

Revised Date: 14 October 2020

Accepted Date: 6 November 2020

Please cite this article as: Francisco, S.N., Kerry, G., Miguel, E., Gilda, C., Federico, D., Andres, M., Linking thermochronological data to transient geodynamic regimes; new insights from kinematic modeling and Monte Carlo sampling of thermal boundary conditions, Journal of South American Earth Sciences (2020), doi: https://doi.org/10.1016/j.jsames.2020.103018.

This is a PDF file of an article that has undergone enhancements after acceptance, such as the addition of a cover page and metadata, and formatting for readability, but it is not yet the definitive version of record. This version will undergo additional copyediting, typesetting and review before it is published in its final form, but we are providing this version to give early visibility of the article. Please note that, during the production process, errors may be discovered which could affect the content, and all legal disclaimers that apply to the journal pertain.

(C) 2020 Published by Elsevier Ltd. 


\section{Conflict of interest}

The authors whose names are listed immediately below certify that they have NO affiliations with or involvement in any organization or entity with any financial interest (such as honoraria; educational grants; participation in speakers' bureaus, membership, employment, consultancies, stock ownership, or other equity interest; and expert testimony or patent-licensing arrangements), or non-financial interest (such as personal or professional relationships, affiliations, knowledge or beliefs) in the subject matter or materials discussed in this manuscript.

\section{Author names:}

Francisco Sanchez Nassif

Kerry Gallagher

Miguel Ezpeleta

Gilda Collo

Federico Dávila

Andres Mora. 


\section{Linking thermochronological data to transient geodynamic regimes; new insights} from kinematic modeling and Monte Carlo sampling of thermal boundary conditions

Authors: Sanchez Nassif, Francisco ${ }^{1}$; Gallagher, Kerry ${ }^{2}$; Ezpeleta, Miguel ${ }^{1}$; Collo, Gilda ${ }^{1}$, Davila, Federico ${ }^{1}$, Mora, Andres ${ }^{3}$

1. Centro de Investigaciones en Ciencias de la Tierra (CICTERRA). Av Velez Sarsfield 1699, Cordoba, Cordoba, Argentina.

2. Geosciences/OSUR, University of Rennes, Campus de Beaulieu, Rennes, 35042, France

3. Ecopetrol, Praia de Botafogo, Brazil

\section{Abstract}

It is common practice to assume values for basal heat flow or basal temperatures as a lower boundary condition for thermo-kinematic models of crustal tectonics. Here, we infer spatial and temporal variations of the paleo-basal temperature from integrated modelling of thermochronological ages, to relate the inferred variations to the geodynamic setting. To this end, we consider the Argentine Precordillera as a natural laboratory, given that its kinematic evolution is relatively well constrained and therefore, the focus can be placed on the variations of its basal thermal state. By means of a simple Monte Carlo sampling approach with thermochronological data as constraints, we infer the paleo-basal temperature history. This is compared to estimates posed by models existing in the literature concerning flat-slab subduction. Our results imply that, given the kinematic models used to date in the area, extremely low temperature gradients $\left(<15^{\circ} \mathrm{C} / \mathrm{km}\right)$ are required to adequately predict the observed thermochronological ages. Substantial cooling of the lithosphere around $10 \mathrm{Ma}$ is also required in order to fit measured values. This agrees with previous thermal simulations carried out in the region. Furthermore, major controls of the thermal architecture on the Argentine Precordillera are implied, thus reigniting the debate on thermal driving mechanisms in the evolution of mountainous settings and their relationship with deeper processes within the Earth, such as on the effects of the flat-slab subduction. 


\section{Introduction}

Thermochronological data have been extensively used as constraints for models of the thermal evolution of the lithosphere (see Reiners and Ehlers, 2005; Guillaume et al., 2013., Dávila and Carter, 2013; Fosdick et al., 2015; and also England and Molnar, 1990; Ring et al., 1999; for a review of cooling processes). In that sense, the growing use of thermochronological data has propelled major advances in kinematic thermochronological modeling in the last two decades (Braun et al., 2012; Almendral et al., 2015, among others). Moreover, inverse thermochronologic modeling carried out under the assumption of constant lower boundary conditions (such as basal temperature or heat flow) has rendered valuable information on heat transfer in settings where the geodynamic evolution is relatively well understood (Braun, 2003; Fillon and van der Beek, 2012; Coutand et al, 2014; Olivetti at al., 2017). In general, the lower boundary conditions are rarely treated as variable (spatially and/or temporally) parameters (although see Schildgen et al., 2009 for an example of transient lower thermal boundary conditions). Furthermore, no studies have focused on inferring transient boundary conditions from thermochronological measurements. Not taking geodynamic variability into account in regions where major changes have clearly occurred (e.g. modification of the subduction angle; see for example Dávila et al., 2018), can lead to equivocal results and conflicting interpretations. These concerns are corroborated by studies demonstrating the thermal evolution of the continental lithosphere is dependent on the evolving geodynamic scenario (Vitorello and Pollack, 1980; Sachse et al., 2016; Ávila and Dávila, 2020). Thus, the relationship between transient geodynamics and thermochronological modeling of the upper crust calls for special attention.

To understand the implications of unsteady subduction and, as would be likely, an unsteady or transient lower boundary condition for the overlying lithosphere, we consider the well-known Argentine Precordillera (AP) as a preliminary case study. Structural reconstructions in the Jachal area (near Jachal city, see Fig. 1; Jordan et al., 1993; Allmendinger and Judge, 2014; Nassif et al., 2019) have been complemented with thermochronological data (Levina et al., 2014; Fosdick et al., 2015; Val et al., 2016; and new data from this work) and estimations of erosion rates (Fosdick et al; 2015; Val et al., 2016; Nassif et al., 2019). These multiple constraints make the Argentine Precordillera of Jachal an ideal test case to assess the potential of extracting novel geodynamic information from measured thermochronological ages. Furthermore, the present work 
seeks to build on previous findings exploring the influence of basal temperatures on thermochronological data (see for instance Shildgen et al., 2009), and also to cast new light on heating mechanisms. As has been previously suggested (Ehlers, 2005; Dávila and Carter, 2013; Nassif et al., 2020, in press), physical phenomena other than burial and denudation processes may play a significant role regarding rates and durations of heating and cooling. Hence, we take advantage of the state-of-the-art knowledge of the Argentine Precordillera to pose questions not directly concerning exhumation and/or erosion. In particular, can we constrain variations of paleo-basal temperatures with kinematic and thermochronological data? What implications may such estimates have on our interpretations and thermochronologically driven conclusions? The present effort addresses those questions by means of Monte Carlo sampling to infer basal temperature values over time. We apply an easy-to-implement statistical framework to compare model predictions with existing and new thermochronological data. These data are complemented with diagenetic indicators (\% Illite to Smectite; see Środoń et al., 1986), the combination of which lets us set bounds on the lower thermal boundary condition, i.e. basal temperature over time. The model results are compared to proposed thermal states in the study region (Gutscher et al., 2000) which are of particular importance given the uncommon nearly-flat subduction angle in the region. We propose that the stochastic sampling approach described here may be suitable for other geological scenarios where inversion of thermochronological data can aid reducing uncertainties of first-order variables present in thermal simulations.

\section{Geological setting}

The Argentine Precordillera (AP) is an intraplate fold-and-thrust belt located at the southern end of the Central Andes foreland. It is composed of N-S trending mountains that record a prolonged Paleozoic to Cenozoic tectonic history, suggested being controlled by subduction processes and the accretion of exotic terranes (Ramos et al, 1986; 2004). Major Andean deformation and uplift in this region have been related to the ongoing flat subduction of the Nazca plate beneath the South American lithosphere (Isacks et al., 1982; Jordan et al., 1983a-b; Kay and Abbruzzi, 1996; Dávila et al., 2018). 
The present-day landscape in the AP shows meridional and sub-parallel thrust sheets separated by seven major thrust faults, named from west to east: Tranca, Caracol W, Caracol E, Blanco, Blanquitos, San Roque, and Niquivil (Fig. 1; Allmendinger and Judge, 2014). Such structures, suggested to be associated with a deep decollement ( $16 \mathrm{~km}$ ), are responsible for the complex scenario outcropping in Jachal section (see Fig 1). Studies of the chronology of motion of the thrustbelt have elucidated its kinematics (Allmendinger and Judge, 2014; Jordan et al., 1993), and have been complemented by recent efforts to estimate Tertiary erosion and deposition (Fosdick et al., 2015; Val et al., 2019; Nassif et al., 2019). Taken together, the structural and thermochronological endeavours in the area have successfully constrained the spatial evolution of the region, but kinematic models relating such deformation to the thermal evolution of the belt remain to be developed. Given that the AP constitutes an exploratory frontier (Pérez et al., 2011), insights into the thermal history experienced by potential source-rocks within the Cambro-Ordovician limestone sequence. (Pérez et al., 2011; see Fig. 1 for reference), are of importance to both researchers and industry.

Regarding its thermal state, the AP has been linked to refrigerated thermal regimes, as it sits over the Chilean-Pampean flat slab segment (see Collo et al., 2018). Shifting of the asthenospheric wedge caused by slab flattening is suggested to produce thermal cooling of the upper crust (Gutscher et al., 2000; English et al. 2003; Álvarez et al. 2014), with evidence of the 'cold state' provided in the Vinchina Basin. Here extremely low heat flow values $\left(<30 \mathrm{~mW} / \mathrm{m}^{2}\right)$ were proposed to explain thermal calibration data (Collo et al., 2011; 2015). Such low heat flow values may have varied with the slab geometry, which has also been constrained in the study region. Several authors (Gutscher et al. 2000; Jordan et al., 2001; Ramos and Folguera, 2009; among others) have postulated the beginning of the flattening episode at $\sim 15-18 \mathrm{Ma}$, with the slab becoming sub-horizontal at $\sim 7-6 \mathrm{Ma}$ (Gutscher et al. 2000; Kay and Mpodozis, 2002). Taking into account the already understood spatial deformation at Jachal (see Fig. 1, above), the available data and interpretations make this region of the Pampean flat slab an ideal scenario to explore the relationship between a) the record of crustal cooling and exhumation, and b) the combined effects of thin-skinned deformation and changes in subduction geometry at the lithospheric scale. 


\section{Methodology}

a) Inversion of time-dependent boundary conditions from thermochronological and kinematics data

131 Using the documented deformational sequence for the AP (see Jordan et al., 1993;

132 Allmendinger and Judge, 2014; Nassif et al.; 2019, and references therein) as a geological

133 reference framework, we used Fetkin (Finite element kinematics; see Almendral et al.,

$1342015)$ to predict thermochronological ages along the thrustbelt. Fetkin is a 2D thermo-

135 kinematic code which takes as input a series of structural sections to forward-model low-

136 temperature thermochronological ages at user-specified locations by solving the heat

137 equation, given as

$$
\frac{\partial T}{\partial t} \rho C=\nabla \cdot(\lambda \nabla T)-(q \rho C \cdot \nabla T)+H
$$

where $T$ is temperature, $t$ is time, $\lambda$ is the thermal conductivity, $\rho$ and $C$ are the density and specific heat capacity, respectively; and $q$ is the rock velocity, determined by the tectonic history of the setting. Rock velocities are obtained directly in Fetkin by tracking the position of material particles throughout the simulation of the structural evolution. $H$ represents heat sources and sinks, which for simplicity, were not included in the models considered here. Moreover, to solve the $2 \mathrm{D}$ form of the heat transfer equation, four boundary conditions; namely $\mathrm{B}_{1}$ (lower), $\mathrm{B}_{2}$ (upper), $\mathrm{B}_{3}$ (right boundary) and $\mathrm{B}_{4}$ (left boundary) are required. In this work, the lower boundary condition, $\mathrm{B}_{4}$, was allowed to vary over time to better represent the geodynamic evolution of the system. The numerical model starts from an equilibrated thermal steady-state, thereafter solving the heat equation considering thrusting kinematics and boundary enforcements.

150 Our thermo-kinematic model for the Jachal AP (see Fig. 1 for location) started at 16 Myrs, 151 when movement along the westernmost thrust, Tranca (see Fig. 1), was triggered (Jordan 152 et al., 1993; Allmendinger and Judge, 2014). Thermo-kinematic calculations were carried 153 out to the present day, with the final model form being equivalent to the outcropping structural configuration today (see Allmendinger and Judge, 2014; Nassif et al., 2019). For 
155 the thermal model calibration, we incorporated 2 sets of unpublished fission track data

156 (processed by Late Andes laboratory, Argentina, see Table 1). Sample J272, belonging to

157 Permian strata within the San Roque nappe (see Fig. 1 for location in the thrustbelt),

158 yielded a central AFT age of $152.3 \pm 12.9 \mathrm{Ma}$. Track lengths measurements were also

159 carried out in this sample, resulting in a unimodal distribution with a mean track length

160 (MTL) of $10.17 \pm 1.68 \mu \mathrm{m}$ (see Table 1 and also Supplementary Material, S1). In the

161 easternmost nappe, Niquivil, analysis in a Silurian sandstone yielded a central AFT age of

$16210.9 \pm 2.1 \mathrm{Ma}$, but no track lengths were observed in this sample. It is highlighted that the

163 two central ages obtained (ages for samples J259 and J272) were concordant (passed the

164 chi-squared test, see Supplementary Material 2) and are also considerably younger than

165 their stratigraphic ages. Moreover, no appreciable relationship between the single grain

166 ages and the kinetic parameter considered, Dpar (measured on each grain) was seen in

167 any sample (see Supplementary Material). These ages are therefore considered to reflect

168 primarily the post-depositional thermal history and are interpreted in terms of the samples'

169 cooling to the surface.

170

\begin{tabular}{|c|c|c|c|c|c|c|c|c|c|c|c|c|c|c|c|}
\hline Sample & $\mathrm{x}$ & $\mathrm{Y}$ & $\begin{array}{c}\mathrm{Z} \\
(\mathrm{m}) \\
\end{array}$ & Geologic unit & Ns & $\mathrm{Ni}$ & $\mathrm{Nd}$ & \begin{tabular}{|c|} 
Rho-d \\
$\left(1 / \mathrm{cm}^{2}\right)$ \\
\end{tabular} & grains & $\begin{array}{l}\text { Dpar } \\
(\mu \mathrm{m})\end{array}$ & $\operatorname{MTL}(\mu \mathrm{m})$ & $\begin{array}{c}\mathrm{U} \\
(\mathrm{ppm})\end{array}$ & $\begin{array}{c}\text { Central } \\
\text { ages (Ma) }\end{array}$ & Disp. & $P\left(X^{2}\right)$ \\
\hline J272 & $68.64^{\circ} \mathrm{W}$ & \begin{tabular}{|c|}
$30.30^{\circ}$ \\
$\mathrm{S}$
\end{tabular} & 1125 & Fm Panacan & 777 & 519 & 10000 & $6.48 \mathrm{E}+05$ & 15 & 1.46 & 10.16 & 37.52 & $\begin{array}{c}152.3+- \\
12.9\end{array}$ & 0.06 & 34.98 \\
\hline$J 259$ & $68.62^{\circ} \mathrm{W}$ & \begin{tabular}{|c|}
$30.31^{\circ}$ \\
$\mathrm{S}$
\end{tabular} & 1195 & Fm Los Espejos & 33 & 314 & 10000 & $6.48 \mathrm{E}+05$ & 21 & 1.36 & $\begin{array}{c}\text { no } \\
\text { lengths }\end{array}$ & 17.21 & $10.9+-2.1$ & 0.13 & 46.51 \\
\hline
\end{tabular}

Table 1. AFT data from this work

173 In addition to the new AFT measurements, data from $3 \mathrm{U}-\mathrm{Th} / \mathrm{He}$ samples are available

174 from the literature (Fosdick et al., 2015; see Fig. 4, results) and these were also

175 incorporated as constraints. Finally, in order to complement the inferences based on the

176 thermochronological data, diagenetic indicators in clays (Smectite to Illite, I/S\%) were also

177 measured along the easternmost nappe, Niquivil; following standard procedures for clay

178 treatment at the clay laboratory at Universidad Nacional de Córdoba (see Środoń et al.,

179 1986; an references therein).

180 Regarding the 2D heat transfer and thermochronological age simulations, the model 181 considers: a) a mesh resolution of 2500 nodes covering the modeled thrust belt ; b) a 
timestep of $1 \mathrm{Myr}$; c) kinetics for AFT and U-Th-Sm/He from Ketcham et al. (2007) and Wolf et al. (1998), respectively; d) an inherited age of 152 Myrs for the apatites in the study region before Andean deformation took place. The last assumption is based on AFT detrital results that registered such age $(152.3 \pm 16 \mathrm{Ma}$; see sample HC07 from Fosdick et al., 2015) in grains from the foreland basin, Huaco (see Fig. 1 for location). Likewise, results (this work) from AFT measurements in an eastern nappe of the thrust belt (San Roque nappe; $152.3 \pm 12.9 \mathrm{Ma}$; see also Supplementary Material); point also to a Mesozoic inherited age of apatite grains before Andean deformation started in the AP (16 $\mathrm{Ma}$ ). The program assumes the same inherited age for all thermochronological systems, which poses no major problems in modeling exercises as long as thermal resetting in $U$ Th-Sm/He samples is guaranteed (as occurs in this work; see results). Radiation damage effects on He retentivity were not incorporated into the modelling (see also Limitations and further insights)

The depth scale of the model, i.e. the depth to the lower thermal boundary condition, was defined to be $20 \mathrm{~km}$. In accordance with lithological characterizations in the area stating that the thrustbelt is mostly composed by siliciclastic sediments (see Allmendinger and Judge, 2014), we assigned a thermal conductivity of $2.5 \mathrm{~W} / \mathrm{m}^{\star} \mathrm{K}$, a density of $2500 \mathrm{Kg} / \mathrm{m}^{3}$ and specific heat of $1000 \mathrm{~J} / \mathrm{kg}^{*} \mathrm{~K}$ (see Hantschel and Kauereauf, 2009; for value references) across the whole model. Given the limited amount of calibration data, a more complex set of thermophysical parameters or the inclusion of heat production, was not justified for this preliminary study. The top boundary condition at mean sea level was set to $23^{\circ} \mathrm{C}$, after climate characterizations in the region (arid to semi-arid for the studied time interval; see Walcek and Hoke, 2012).

As the aim of this work is to infer the lower thermal boundary condition (temperature at $20 \mathrm{~km}$ ), values for this parameter were allowed to vary in the range 100$800^{\circ} \mathrm{C}$, corresponding to very low $\left(5^{\circ} \mathrm{C} / \mathrm{km}\right)$ to high $\left(40^{\circ} \mathrm{C} / \mathrm{km}\right)$ thermal gradients (see Hantschel and Kauereauf, 2009). These are broadly equivalent to a range in heat flow of 10 to $100 \mathrm{mWm}^{-2}$. To allow for some time dependence, and following thermal numerical models involving slab-flattening processes (Gutscher et al., 2000), we parameterized the basal temperature history in 3 stages, in a step-function manner, with a constant but unknown value in each stage. The time intervals considered for each stage were 1) 16-8 $\mathrm{Ma}, 2$ ) 8-4 Ma and 3) $4 \mathrm{Ma}$ to present (see Fig. 2). The time interval of the first stage was selected to be relatively wide as that the slab-flattening process started around $20 \mathrm{Ma}$ (Kay 
and Mpdozis, 2002), and that its associated thermal effects would not have been perceived before $10 \mathrm{Ma}$ in the upper crust, equivalent to the depth scale of our model (see Gutscher et al., 2000; Jaupart and Mareschal, 2010). Using simple Monte Carlo (MC) sampling we select candidates for the basal temperatures in each time interval from the temperature range defined earlier. To avoid drawing non-physical candidates (for example, "scissor-like" ones implying rapid and large oscillations in the basal temperature), our Monte Carlo sampling proceeded as follows: First, we drew a value from a uniform distribution between $100^{\circ} \mathrm{C}(\mathrm{T} \mathrm{min})$ and $800{ }^{\circ} \mathrm{C}(\mathrm{T} \max )$, corresponding to the first time interval (16 to $8 \mathrm{Ma}$ ). Then, we drew a second value (part 2) from a uniform distribution centered on the candidate value in the first time interval and extending $200^{\circ} \mathrm{C}$ on either side. This large range $\left(400^{\circ} \mathrm{C}\right)$ was set to ensure that a wide set of physically plausible possibilities could be tested. The same prior lower and upper limits set $\left(T_{\min }=100^{\circ} \mathrm{C}, T_{\max }\right.$ $=800^{\circ} \mathrm{C}$ ) as for the first part were also enforced in this instance, so samples were modified accordingly when necessary (for example when values from the first draw corresponded to temperatures near a limit). The basal temperatures for the first and second stages (see Fig. 2) were constant in space, consistent with subduction numerical models that suggest no major lateral variation in the relatively short spatial scale defined by the AP, at the depth scale concerned by this work (see 2D predictions in Gutscher et al., 2000; Gutscher and Peacock, 2003; Manea and Manea, 2011; and also 3D models in Ji et al, 2017; see also Fig. 2). Finally, a candidate model was drawn for the final stage (part 3; $4 \mathrm{Ma}$ to present; Fig 2), using constrained sampling conditional on the value for the second stage, as described previously. For this final stage, we also allowed for spatial variation for the basal temperature (see Fig. 2) as flat-slab Andean thermal models predict an appreciable gradient in the lateral direction (west-east) for this time interval (4 Ma to present; see Gutscher et al., 2000). Hence, a candidate model for this part (3) consisted of two values, both drawn from the same distribution (a uniform centered on the value for previous stage; 2). 10000 iterations of the process above described were performed, and the proposed lower boundary condition temperature history were then entered into Fetkin to run a thermal simulation for each iteration. As the final stage of a candidate model consisted of two values (at the lateral boundaries), the values were interpolated linearly in space in the Fetkin environment. A Python program to parallelize thermal modeling calculations carried out by the Fetkin algorithm was deployed. To measure the agreement of predictions from the thermal model with the observed data, we adopted the following misfit expression $(\varphi)$ 


$$
\varphi=\sqrt{\sum_{i=1}^{N} \sum_{j=1}^{M} \frac{\left({ }^{i} \alpha_{j, \bmod }-{ }^{i} \alpha_{j, \text { sam }}\right)^{2}}{{ }^{i} \sigma_{j}}}
$$

where $N$ the number of data sets and $M$ the samples in each data set, $\alpha_{j, \text { mod }}$ the modeled age for a particular set of parameters and $\alpha_{j, \text { sam }}$ the sampled value (measured age). ${ }^{i} \sigma_{j}$ refers to the data uncertainty. Following Valla et al. (2010), we adopted an uncertainty of 0.5 Myrs to equally weight all data in terms of the difference between the observed and predicted ages.

\section{b) Additional views from classical inverse thermal history modelling}

256 To complement insights derived from the 2D thermochronological simulations, we used 257 inverse thermal history modeling for samples J259 and J272, using the software HeFTy (see Ketcham, 2005). To account for the depositional history of each sample, as well as episodes of heating (potential resetting) before the period concerned by this work (16 Ma to present), the inverse modeling exercises were set considering the following constraints:

\begin{tabular}{|c|c|c|c|}
\hline Sample & $\begin{array}{l}\text { Time } \\
(\mathrm{Ma})\end{array}$ & $\begin{array}{l}\text { Temp. } \\
\text { range }\left({ }^{\circ} \mathrm{C}\right)\end{array}$ & Rationale \\
\hline \multirow{5}{*}{$J 272$} & $400-280$ & $>170$ & simulate provenance \\
\hline & $300-280$ & $0-30$ & sediment accumulation \\
\hline & $260-80$ & $60-140$ & burial heating \\
\hline & $60-23$ & $20-45$ & $\begin{array}{l}\text { Paleozoic rocks should have been close to the surface } \\
\text { anytime in the Cenozoic, as implied by the Neogene/Permian } \\
\text { unconformity in the maps }\end{array}$ \\
\hline & $23-0$ & $60-100$ & $\begin{array}{l}\text { burial and heating of Paleozoic rocks as Andean-related } \\
\text { subsidence took place }\end{array}$ \\
\hline \multirow{5}{*}{$J 259$} & $500-440$ & $>170$ & simulate provenance \\
\hline & $440-420$ & $0-30$ & sediment accumulation \\
\hline & $300-90$ & $60-140$ & burial heating \\
\hline & $60-23$ & $20-45$ & $\begin{array}{l}\text { Paleozoic rocks should have been close to the surface } \\
\text { (but deeper than sample J259, and therefore hotter) } \\
\text { anytime in the Cenozoic, as implied by the Neogene/Permian } \\
\text { unconformity in the maps }\end{array}$ \\
\hline & $23-0$ & $60-100$ & $\begin{array}{l}\text { burial and heating of Paleozoic rocks as Andean-related } \\
\text { subsidence took place }\end{array}$ \\
\hline
\end{tabular}


Table 2. Constraints considered in classical inverse thermal modeling.

\section{Results and discussion}

\section{a) Misfit distribution}

266

267

268

269

270

271

272

273

Results from the MC inversion are shown in Fig. 2. Fig. 2A shows the AP kinematics used after Nassif et al (2019), which considered an in-sequence thrustbelt deformation starting at $16 \mathrm{Ma}$. Fig. 2B displays a "noodle plot" of thermal candidates for each of the 3 periods considered (16 Myrs to 8 Myrs, 8 Myrs to 4 Myrs, 4 Myrs to 0 Myrs), and their respective misfit values. Misfits were normalized for this figure to a $0-1$ scale, with 0 representing the lowest misfit observed (best agreement between model predictions and data) and 1 the highest (worst agreement between model predictions and data). We note that a normalized misfit value of 0 does not represent a perfect agreement between data and predictions. The distance along the AP axis is also shown rescaled (-1 to 1 representing west to east; see Fig. 2). Finally, Fig. 2C shows 1D marginal distributions obtained via Neighborhood Algorithm Bayes (see Sambridge, 1999), along with deterministic temperature estimates at the base of the model $(20 \mathrm{~km})$ after the flat slab subduction model of Gutscher et al (2000). Best-fit temperature candidates are also shown in Fig. 2C for clarity (see red lines).

We remark that the conditional dependence (or correlation) between parameters from each of the 3 periods plays a major role regarding the misfit values. For example, normalized misfit values for $\mathrm{T}=200^{\circ} \mathrm{C}$ in the first stage (16 Myrs to 8 Myrs; see Fig. 2B), vary between 0.7 and 0.1 , depending on the values of the other 3 parameters. Some combinations of this candidate $\left(T=200^{\circ} \mathrm{C}\right)$ with candidates from the other two stages yielded better misfits than others, demonstrating a conditional dependence or trade-off among values drawn for each of the 3 periods. Overall, however, basal temperatures in the range between $400^{\circ} \mathrm{C}$ to $800^{\circ} \mathrm{C}$ represent poor models (high normalized misfit, 0.6 or higher; see Fig. 2) for all of the 3 stages considered, regardless of how they were combined.

Lower values of misfit for the first stage (16 Myrs to 8 Myrs) are obtained when candidates are in the $300^{\circ} \mathrm{C}-100^{\circ} \mathrm{C}$ range (with some conditional dependence on the other two 
periods, as discussed above). Misfit values are lower when candidates are around $200^{\circ} \mathrm{C}$ to $100^{\circ} \mathrm{C}$ in the second stage ( $8 \mathrm{Myrs}$ to $4 \mathrm{Myrs}$ ), implying that basal temperatures (at 20 $\mathrm{km}$ depth) in the AP for this time interval may have decreased. This statement also holds true for the third stage (4 Myrs to present). However, since a lateral variation of temperature was allowed for this time interval of the simulations, the results appear more dispersed across the temperature axis relative to the second phase. Furthermore, our MC inversion results suggest that heat coming into the base of the AP $(20 \mathrm{~km})$ during the Miocene may have never led to temperatures in excess of $300^{\circ} \mathrm{C}$, implying low thermal gradients $\left(\sim 15^{\circ} \mathrm{C} / \mathrm{km}\right.$, or heat flow about $\left.30 \mathrm{mWm}^{-2}\right)$.

Marginal distributions obtained for each variable considered (Fig. 2C) using the NA resampling method (see Sambridge, 1999) corroborate previous comments in regards to temperature reduction after $8 \mathrm{Ma}$ (see Fig. $2 \mathrm{C}$ ), as the range of temperatures in the marginal pdf is strongly peaked at lower values ( 2 modes seen in the distribution) for the interval 8-4 Ma. It can also be noted that marginal distributions from T1 and T2 barely overlap, disclosing the diminution in basal temperatures after $8 \mathrm{Ma}$ (see Fig. 2C). The 2 distributions for the last stage (in the period 4 to $0 \mathrm{Myrs}, \mathrm{W}$ and $\mathrm{E}$ ) span a similar range to the 2nd stage, and both are peaked at low values $\left(100-120^{\circ} \mathrm{C}\right)$.

To complement the previous assertions on conditional dependence, we used the same resampling approach to construct the $2 \mathrm{D}$ marginal distributions for each combination of variables analyzed (T1, T2, T3, T4; see Fig. 3) and we also calculated the correlation matrix for the 4 parameters (Fig. 3; bottom). These results show that there are indeed correlations between parameters, the strongest being between the parameters for stages 1 (T1) and 2 (T2) (correlation coefficient of -0.67 ), implying a trade-off such that as T1 increases T2 decreases. This is also manifested in the orientation of the contours in the $2 \mathrm{D}$ marginal distribution for these two parameters. There are less strong correlations of stage 1 and stage 2 with the parameter in the west (T3) from stage 3 (correlation coefficients of -0.25 , and 0.26 respectively, implying slightly negative and positive correlations). The temperature parameter in east (T4) has correlation coefficients of $<10^{-2}$ with the other 3 parameters, so effectively no correlation. Both the $1 \mathrm{D}$ and $2 \mathrm{D}$ marginal distributions also demonstrate that the more probable values for all 4 temperature parameters are below $300^{\circ} \mathrm{C}$, highlighting the dominantly cold thermal regime since $16 \mathrm{Ma}$.

b) Comparison with the Andean flat-slab subduction model of Gutscher et al. (2000) 
324 The results presented in this work are consistent with previous subduction models

325 (Gutscher et al., 2000; Gutscher and Peacock, 2003; Manea and Manea, 2011), that 326 propose refrigerated thermal architectures after slab flattening (see estimates from 327 Gutscher et al., 2000; Fig. 2C). Moreover, the trends from our best-fit models agree well 328 with the pronounced cooling after c.a. 10 Myrs proposed by Gutscher et al. (2000; see Fig. 329 2C). The main difference between our best-fit result and Gutscher et al. (2000) occurs for 330 the period from 8 to 4 Myrs (Fig. 2C), where our inferred best temperature values (around $331100^{\circ} \mathrm{C}$ for T2) are lower than those after Gutscher et al. (2000; around $200^{\circ} \mathrm{C}$ ). However, 332 the marginal distributions suggest that there is a local maximum (equivalent to a local 333 minimum for the misfit) around $200^{\circ} \mathrm{C}$, so the results overall are consistent with Gutscher et al. (2000). More data are required to resolve more definitively whether the thermal effect of the flat slab had already perturbed the upper crust by 8 Myrs (for our best model) or if this effect arrived at a later stage (as implied by Gutscher et al., 2000). Regarding the last 4 Myrs, our best-fit candidate implies the same eastward increase in temperature as in the Gutscher et al. (2000) model, but again more data are needed to better constrain the basal temperature values for that period. A lack of resolution is implied by the variable orientations among basal temperature candidates and associated lack of correlation for that interval (see Fig 2B, 2C and Fig. 3). We note that the implied present day gradients resulting from all the lower misfit candidates $\left(\sim 13^{\circ} \mathrm{C} / \mathrm{km}\right.$ to $\left.5^{\circ} \mathrm{C} / \mathrm{km}\right)$ are consistent with low thermal gradients derived from borehole measurements (Collo et al, $2018 ; 18{ }^{\circ} \mathrm{C} / \mathrm{Km}$ ). Collo et al. (2018) highlighted a westward reduction of thermal gradients between $64^{\circ} \mathrm{W}$ and $68^{\circ} \mathrm{W}$ attributable to a flat-slab.

\section{c) Discussion on modeled thermochronological ages}

Results obtained for modeled thermochronological data are shown in Fig. 4, along with the interpreted structural state of the Jachal AP for the present day (after Nassif et al., 2019; Allmendinger and Judge, 2014). Table 3 summarizes the measured (from this and other works) and modeled values. We note that although the thermochronological ages exhibit significant variation along the transect (see AFT ages of Permian and Silurian rocks in the easternmost nappe; $152.3 \pm 12.9$ Myrs and 10.9 \pm 2.1 Myrs, respectively; Fig. 4); predicted ages (obtained with the best-fit model) and measured ages follow the same trend. In particular, the thermal resetting of U-Th/He samples from Blanco (JT07), Blanquitos (JT12) and Niquivil (JT01) is well replicated, with all ages implying Andean cooling (see Fig. 4 and Fig. 1 for reference). We remark that modeled U-Th/He age of sample J701 (8.4 Myrs) 
implies, like the measured age (12.3 \pm 1.4 Myrs; Fosdick et al., 2015), cooling that predates deformation along Niquivil thrust (see Fig. 4). This inference is significant given that kinematic reconstructions point to a major burial episode at that time $(\sim 4 \mathrm{Km}$ at 5 Myrs, see Nassif et al., 2019), which might be hard to reconcile with the observed U-Th/He ages, which are older than Niquivil faulting (see Fig. 4, samples JT01 and JT259). Modeling incorporating a normal gradient $\left(20^{\circ} \mathrm{C} / \mathrm{km}\right.$ to $\left.30^{\circ} \mathrm{C} / \mathrm{km}\right)$ would fail to reproduce such a situation, producing totally reset ages that reflected later cooling around the time of Niquivil thrust activation (5 Myrs or less; see also Nassif et al., 2020; in press).

\begin{tabular}{|c|c|c|c|c|c|c|}
\hline & Sample & Depositional age & $\begin{array}{l}\text { Measured } \\
\text { age (Ma) }\end{array}$ & $\begin{array}{l}\text { Measured } \\
\text { MTL ( } \mu \mathrm{m}, \mathrm{c}- \\
\text { axis } \\
\text { corrected) }\end{array}$ & $\begin{array}{l}\text { Modeled } \\
\text { age (Ma) }\end{array}$ & $\begin{array}{l}\text { Modeled } \\
\text { MTL }(\mu \mathrm{m})\end{array}$ \\
\hline AFT & J259 (this work) & Silurian & $10.9 \pm 2.1$ & & 23.14 & 12.3 \\
\hline AFT & J272 (this work) & Permian & $152.30 \pm 12.9$ & $12.57 \pm 1.18$ & 114.321 & 12.63 \\
\hline $\begin{array}{l}\text { U-Th- } \\
\mathrm{Sm} / \mathrm{He}\end{array}$ & $\begin{array}{l}\text { JT07 (Fosdick } \\
\text { et al., 2015) }\end{array}$ & Silurian & $14.1 \pm 1.0$ & & 7.85 & \\
\hline $\begin{array}{l}\text { U-Th- } \\
\mathrm{Sm} / \mathrm{He}\end{array}$ & $\begin{array}{l}\text { JT01 (Fosdick } \\
\text { et al., 2015) }\end{array}$ & Silurian & $12.3 \pm 1.4$ & & 8.42 & \\
\hline $\begin{array}{l}\text { U-Th- } \\
\mathrm{Sm} / \mathrm{He}\end{array}$ & $\begin{array}{l}\text { JT012(Fosdick } \\
\text { et al., 2015) }\end{array}$ & Permian & $11.7 \pm 4.1$ & & 6.8 & \\
\hline
\end{tabular}

Table 3. Modeled and measured ages and track lengths

The AFT modeled ages agree with observations (see also supplementary material), both implying partial annealing of fission tracks during Andean structuration (see Fig. 4). The high content of Illite in I/S mixed layers (around 80\%; R3; see Fig.4 and supplementary material) in AFT Permian and Silurian samples (J272 and J259, respectively) tentatively imply that Paleozoic rocks were heated above temperatures over $100^{\circ} \mathrm{C}$ (see Velde and 
Vasseur, 1992; Huang et al, 1993; among others). Given that maximum temperatures rendered by the best-fit model for partially-reset AFT Silurian sample J259 do not exceed the $90-100^{\circ} \mathrm{C}$ range (see Fig. 4, inset), and that AFT age of Permian sample J272 points to a very minor degree of thermal resetting (152.3 \pm 12.9 Myrs, Fig. 4), our results suggest that temperatures in excess of $120^{\circ} \mathrm{C}$ might have been reached prior to Tertiary deformation. Such a proposal is consistent with 1D modeling exercises previously performed for the AP (Fosdick et al., 2015), which suggested temperatures always below $80^{\circ} \mathrm{C}$ for the period modeled in this work (16 Myrs to present). We note that the proposed pre-Andean heating might imply that Cambro-Ordovician marine sedimentary rocks (see Fig.1), suggested to be potential oil source rocks (see Pérez et al., 2011; Fig. 1), would have reached temperatures in the oil window before the Miocene orogenesis, therefore ruling out Tertiary-trap hydrocarbon accumulation.

\section{d) Complementary views from 1D thermal models}

As discussed previously in the methodology, inverse thermal models using HeFTy for the two AFT samples (J272 and J259) were performed. The inverse thermal model for sample J272 considered age and length measurements, since both were available. In contrast, the inverse thermal model for sample J259 only had age measurements as constraints, as no confined lengths were observed (see SM1) for that sample. Fig. 5 shows the results for both samples, outlining major observations that can be obtained from the time-temperature paths inverted, which can be summarized as follows:

i) Sample J272 (San Roque nappe, see Fig. 5A): the thermal history of this Permian sample exhibits two episodes of thermal resetting; at Mesozoic and at Miocene. Full thermal resetting of sample J272 at 220 Ma points to an old (>150 Ma) remnant age of the sample by the time it underwent Andean-related burial and consequent heating. Such Andean heating only promoted maximum temperatures around $80^{\circ} \mathrm{C}$, producing only partial annealing in fission tracks. This partial annealing was followed by rapid Neogene cooling, which might be interpreted in terms of thrusting and kinematics of the AP (see Fosdick et al., 2015; Val et al., 2016, Nassif et al., 2019). Moreover, according to the HeFTy inverse model (and also 2D kinematic simulations), the sample J272 was never heated by temperatures above $90^{\circ} \mathrm{C}$ during the Tertiary, so the remnant age was not altered substantially during Andean deformation. Such partial thermal-resetting during Andean tectonics remarks the strong influence of the basal boundary conditions on the 
404

405

406

407

408

409

410

411

412

413

414

415

416

417

418

419

420

421

422

423

424

425

426

427

428

429

430

431

432

433

434

435

thermal history of the thrust belt: the sample underwent cooling since $10 \mathrm{Ma}$ despite the fact that, indeed, the sample was being substantially buried (see sedimentation estimation in Nassif et al., 2019) as a consequence of thrusting-related syn-sedimentation.

ii) Sample J259 (Niquivil nappe, see Fig. 5B): the degree of Miocene thermal resetting in this sample remains unconstrained by thermochronological data alone, as the lack of length data means that many possible models can explain the age measurements. However, considering similar constraints as those imposed for sample J272, the inverse model rendered corroborates previous assertions regarding a Miocene cooling episode not linked to rock exhumation but to transient boundary conditions instead. Alike sample $\mathrm{J} 272$, the thermal history of sample J259 also points to a cooling event after 10 Myrs, which seems counterintuitive as by this time most volume of the Argentine Precordillera was being translated from western nappes to eastern ones (see Fosdick et al., 2015; Val et al., 2016, Levina et al., 2014; and kinematics in Nassif et al., 2019), therefore implying substantial burial and deepening of sediments within the Niquivil block; i.e. what might be considered the opposite of cooling. Hence, the inverted Andean thermal evolution of sample J259, to some extent unpaired with the kinematics and sedimentation of the thrust belt, discloses the major effects of the flat-slab subduction (and its associated changes in basal heat flow) on time-temperature paths and thermochronological ages.

\section{e) Regional geodynamic context}

Although a complex thermal structure is inferred for this region (Sánchez et al. 2019) and some discrepancies exist regarding the associated thermal regime during the transition from normal to flat subduction (see Collo et al., 2011 and Goddard and Carrapa, 2018), the cooling of the thermal regime by 8 Myrs implied by our models is consistent with the inferred low heat flow in the region based on borehole, seismic, thermochronological and magnetic data (Marot et al., 2014; Collo et al., 2018; Sánchez et al. 2019) and with the extremely low gradients in the Huaco foreland basin proposed by authors such as Dávila and Carter (2013), Richardson et al. (2013), Hoke et al. (2014), Bense et al. (2014), and Collo et al. (2018); as well as with those recorded for other flat slab regions (eg. Dumitru et al., 1991, Gutscher 2002, Manea and Manea 2011).

Moreover, our results support the proposals of Dávila \& Carter (2013), who suggested that thermochronological ages in this region not only record erosion/exhumation, but also changing subduction geometry and dynamics. Building on these previous qualitative 
propositions, the present effort represents the first attempt to quantify the influence of the Pampean flat slab subduction in the thermal regime of the AP. Our findings are similar to those seen in deep Vinchina Basin (around $10 \mathrm{~km}$ depth), where sediments belonging to the depocenter were not thermally reset during Miocene deformation (Collo et al., 2011, 2015, 2018). Such unreset AFT ages (and also U-Th/He ages, see sample JT01) within the AP, a fold-and-thrust belt where the magnitude of erosion is probably $>5 \mathrm{~km}$ (see Zapata and Allmendinger, 1996; Jordan et al., 2001; Fosdick et al., 2015, Val et al., 2016; Nassif et al., 2019), suggest that other heating/cooling mechanisms apart from burial and exhumation may need to be invoked. The reduction of heat transfer from below by fluid flow (Nassif et al., 2020, in press) would also allow higher basal temperatures to fit the measured thermochronological data. However, the extent of fluid flow through the AP is yet to be precisely quantified (Lynch and van der Plujim, 2017) and only then can such effects be better understood.

\section{f) Limitations and further insights}

Although the numerical model performed in this study satisfactorily explains the thermochronological data set, we highlight that model results could be enhanced by considering the following: a) incorporation of radiation damage effects in the AHe analysis; which, as discussed by Zapata et al. (2020), might be a first-order factor conditioning UTh-Sm/He thermochronological measurements (and interpretations) near the study region. Moreover, overlapping of AHe and AFT ages in sample J259; might point in that direction, or could also just reflect rapid cooling across the partial retention/annealing zones. b) Consideration of isostatic effects in the kinematic and erosional model of Nassif et al. (2019), which could reduce the amount of eroded material and thus, the thickness of the Neogene sedimentary column considered in the simulations (see also McQuarrie and Ehlers, 2015); c) refinement of the numerical model by incorporating physical phenomena not considered in this work (for instance radiogenic heat production, variable thermophysical parameters or fluid flow), which could lead to different basal temperatures that also fit the thermochronological constraints. However, as the main aim of this work was to explore a new way of exploiting thermochronological data; i.e. inversion of timedependent basal temperatures, the methods considered and the simplifications implicit in them is sufficient to demonstrate the potential of this approach. 
469

470

471

472

473

474

475

476

477

478

479

480

481

482

The basal temperature inversion exercise presented here, based on classic Monte Carlo sampling, shows an alternative use of thermochronological data, that is, to try and constrain time and spatial variations in the lower thermal boundary condition (at $20 \mathrm{~km}$ ) for thermo-kinematic models. The motivation is to link geodynamically induced thermal signals from the deeper Earth with those related to upper-crust structural kinematics and to shed more light on the nature of heat transfer in subduction settings. However, this may seem counter-intuitive as the thermochronological data are sensitive to temperatures $<150^{\circ} \mathrm{C}$, and also the inversion approach and model parameterizations we used were simple; the preliminary results are promising. This is in part due to the very low basal temperatures associated with the refrigerated thermal regime associated with flat subduction, suggesting similar (or more sophisticated) approaches and other types of higher temperature thermochronological data (e.g. He dating of zircon, ${ }^{40} \mathrm{Ar} /{ }^{39} \mathrm{Ar}$ on feldspar, U-Pb on apatite) may be usefully applied in other areas where the structural evolution and the geodynamic regime can be constrained.

\section{Acknowledgements}

The present work was funded by CONICET, FONCYT and SECYT.

\section{References}

Allmendinger, R. W., \& Judge, P. A. (2014). The Argentine Precordillera: A foreland thrust belt proximal to the subducted plate. Geosphere, 10(6), 1203-1218.

Almendral, A., Robles, W., Parra, M., Mora, A., Ketcham, R. A., \& Raghib, M. (2015). FetKin: Coupling kinematic restorations and temperature to predict thrusting, exhumation histories, and thermochronometric agesCoupling Kinematic Restorations and Temperature. AAPG Bulletin, 99(8), 1557-1573.

Álvarez O., Nacif S., Gimenez M., Folguera A., Braitenberg A. (2014). Goce derived vertical gravity gradient delineates great earthquake rupture zones along the Chilean margin. Tectonophysics 622: 198-215 
496

497

498

499

500

501

502

503

504

505

506

507

508

509

510

511

512

513

514

515

516

517

518

519

520

521

522

523

Ávila, P., Dávila, F. Lithospheric thinning and dynamic uplift effects during slab window formation, southern Patagonia (45 $-55^{\circ}$ S). Journal of Geodynamics 133 (2020): 101689.

Bense, F.A., Wemmer, K., Löbens, S., Siegesmund, S., (2014). Fault gouge analyses: K-Ar illite dating, clay mineralogy and tectonic significance-a study from the Sierras Pampeanas, Argentina. Int. J. Earth Sci. 103, 189-218

Braun, J. (2003). Pecube: A new finite-element code to solve the 3D heat transport equation including the effects of a time-varying, finite amplitude surface topography. Computers \& Geosciences, 29(6), 787-794.

Braun, J., Van Der Beek, P., Valla, P., Robert, X., Herman, F., Glotzbach, C., Pedersen, V., Perry, C., Simon-Labric, T. and Prigent, C. (2012). Quantifying rates of landscape evolution and tectonic processes by thermochronology and numerical modeling of crustal heat transport using PECUBE. Tectonophysics, 524, 1-28.

Collo G, Dávila FM, Nóbile J, Astini RA, Gehrels G (2011) Clay mineralogy and thermal history of the Neogene Vinchina Basin, central Andes of Argentina: Analysis of factors controlling the heating conditions. Tectonics 30: 1-18

Collo G, Dávila FM., Teixeira W, Nóbile JC, Sant' Anna LG, Carter A (2015) Isotopic and thermochronologic evidence of extremely cold lithosphere associated with a slab flattening in the Central Andes of Argentina. Basin Research. doi:10.1111/bre.12163

Collo, G., Ezpeleta, M., Dávila, F.M., Giménez, M., Soler, S., Martina, F., Ávila, P., Sánchez, F., Calegari, R., Lovecchio, J. and Schiuma, M., (2018). Basin Thermal Structure in the ChileanPampean Flat Subduction Zone. In The Evolution of the Chilean-Argentinean Andes (pp. 537-564). Springer, Cham.

Coutand, I., Whipp Jr, D. M., Grujic, D., Bernet, M., Fellin, M. G., Bookhagen, Landry, K., Ghalley, S., \& Duncan, C. (2014). Geometry and kinematics of the Main Himalayan Thrust and Neogene crustal exhumation in the Bhutanese Himalaya derived from inversion of multithermochronologic data. Journal of Geophysical Research: Solid Earth, 119(2), 1446-1481.

Dávila, F. M., Carter, A. (2013). Exhumation history of the Andean broken foreland revisited. Geology, 41(4), 443-446. 
Dávila, F.M., Lithgow-Beterlloni, C., Martina, F. Avila, P., Nóbile, J.C, Collo, G., Ezpeleta, M., Canelo, H., Sanchez-Nassif, F. (2018). Mantle influence on Andean and pre-Andean topography. In "The making of the Chilean-Argentinean Andes" (Eds. 7). pp. 372-395. Springer International Publishing. Alemania.

Dávila, F. M., Ávila, P., \& Martina, F. (2019). Relative contributions of tectonics and dynamic topography to the Mesozoic-Cenozoic subsidence of southern Patagonia. Journal of South American Earth Sciences, 93, 412-423.

Dumitru, T.A., Gans, P.B., Foster, D.A., Miller, E.L., (1991). Refrigeration of the western Cordilleran lithosphere during Laramide shallow-angle subduction. Geology 19, 1145-1148.

Ehlers, T. A. (2005). Crustal thermal processes and the interpretation of thermochronometer data. Reviews in Mineralogy and Geochemistry, 58(1), 315-350.

England, P., \& Molnar, P. (1990). Surface uplift, uplift of rocks, and exhumation of rocks. Geology, 18(12), 1173-1177.

English J., Johnston, T., Wang, K. (2003) Thermal modeling of the Laramide orogeny: Testing the flat slab subduction hypothesis. Earth and Planetary Science Letters 214: 619-632

Fillon, C., van der Beek, P. (2012). Post-orogenic evolution of the southern Pyrenees: Constraints from inverse thermo-kinematic modelling of low-temperature thermochronology data. Basin Research, 24(4), 418-436.

Fosdick, J. C., Carrapa, B., \& Ortíz, G. (2015). Faulting and erosion in the Argentine Precordillera during changes in subduction regime: Reconciling bedrock cooling and detrital records. Earth and Planetary Science Letters, 432, 73-83.

Goddard, A. L. S., Carrapa, B. (2018). Using basin thermal history to evaluate the role of MiocenePliocene flat-slab subduction in the southern Central Andes ( $27^{\circ} \mathrm{S}-30^{\circ} \mathrm{S}$ ). Basin Research, 30(3), 564-585.

Guillaume, B., Gautheron, C., Simon-Labric, T., Martinod, J., Roddaz, M., \& Douville, E. (2013). Dynamic topography control on Patagonian relief evolution as inferred from low temperature thermochronology. Earth and Planetary Science Letters, 364, 157-167. 
551 Gutscher, Marc-André, René Maury, Jean-Philippe Eissen, and Erwan Bourdon. Can slab melting be

552 caused by flat subduction?. Geology 28, no. 6 (2000): 535-538.

553 Gutscher, M.-A. (2002). Andean subduction styles and their effect on thermal structure and 554 interplate coupling. Journal of South American Earth Sciences, 15 (1), 3-10. doi:10.1016/s0895555 9811(02)00002-0

556 Gutscher, M. A., \& Peacock, S. M. (2003). Thermal models of flat subduction and the rupture zone 557 of great subduction earthquakes. Journal of Geophysical Research: Solid Earth, 108(B1), ESE-2.

558 Hantschel, T., \& Kauerauf, A. I. (2009). Fundamentals of basin and petroleum systems modeling. 559 Springer Science \& Business Media.

560 Hoke, G.D., Giambiagi, L.B., Garzione, C.N., Mahoney, J.B., Strecker, M.R., 2014. Neogene 561 paleoelevation of intermontane basins in a narrow, compressional mountain range, southern 562 Central Andes of Argentina. Earth Planet. Sci. Lett. 406, 153-164.

563 Huang, W. L., Longo, J. M., \& Pevear, D. R. (1993). An experimentally derived kinetic model for 564 smectite-to-illite conversion and its use as a geothermometer. Clays and Clay Minerals, 41(2), 162565177.

566 Isacks, B., Jordan, T., Allmendinger, R., Ramos, V.A., (1982). La segmentaci6n tectónica de los 567 Andes Centrales y su relaci6n con la placa de Nazca subductada. V Congr. Latinoamericano Geol., 568 Buenos Aires, Actas, III: 587-606.

569 Jaupart, C., Mareschal, J. C. (2010). Heat generation and transport in the Earth. Cambridge 570 University Press. https://doi.org/10.1017/СBO9780511781773

571 Ji, Y., Yoshioka, S., Manea, V. C., Manea, M., \& Matsumoto, T. (2017). Three-dimensional 572 numerical modeling of thermal regime and slab dehydration beneath Kanto and Tohoku, Japan. 573 Journal of Geophysical Research: Solid Earth, 122(1), 332-353.

574 Jordan, T.E., Isacks, B., Ramos, V.A., Allmendinger, R.W., (1983a). Mountain building in the Central 575 Andes. Episodes, 1983(3): 20-26.

576 Jordan, T.E., Isacks, B., Allmendinger, R., Brewer, J., Ramos, V.A., Ando, C., (1983b). Andean 577 tectonics related to geometry of subducted plates. Geol. Soc. Am. Bull., 94(3): 341-361. 
578

579

580

581

582

583

584

585

586

587

588

589

590

591

592

593

594

595

596

597

598

599

600

601

602

603

Jordan, T. E., Allmendinger, R. W., Damanti, J. F., \& Drake, R. E. (1993). Chronology of motion in a complete thrust belt: the Precordillera, 30-31 S, Andes Mountains. The Journal of Geology, 101(2), 135-156.

Jordan T.E., Schlunegger F., Cardozo N. (2001) Unsteady and spatially variable evolution of the Neogene Andean Bermejo Foreland Basin, Argentina. Journal of South American Earth Sciences 14:775-798

Kay, S. M., Abbruzzi, J. M., (1996). Magmatic evidence for Neogene lithospheric evolution of the central Andean "flat-slab" between $30 \mathrm{~S}$ and $32 \mathrm{~S}$. Tectonophysics 259.1-3

Kay SM, Mpodozis C (2002) Magmatism as a probe to the Neogene shallowing of the Nazca plate beneath the modern Chilean flat-slab. Journal of South American Earth Sciences 15: 39-57

Ketcham, R. A. (2005). Forward and inverse modeling of low-temperature thermochronometry data. Reviews in mineralogy and geochemistry, 58(1), 275-314.

Ketcham, R. A., Carter, A., Donelick, R. A., Barbarand, J., \& Hurford, A. J. (2007). Improved modeling of fission-track annealing in apatite. American Mineralogist, 92(5-6), 799-810.

Levina, M., Horton, B. K., Fuentes, F., \& Stockli, D. F. (2014). Cenozoic sedimentation and exhumation of the foreland basin system preserved in the Precordillera thrust belt (31-32 S), southern central Andes, Argentina. Tectonics, 33(9), 1659-1680.

Lynch, E. A., van der Pluijm, B. (2017). Meteoric fluid infiltration in the Argentine Precordillera foldand-thrust belt: Evidence from $\mathrm{H}$ isotopic studies of neoformed clay minerals. Lithosphere, 9(1), 134-145.

Manea, V. C., Manea, M. (2011). Flat-slab thermal structure and evolution beneath central Mexico. Pure and Applied Geophysics, 168(8-9), 1475-1487.

Marot, M., Monfret, T., Gerbault, M., Nolet, G., Ranalli, G., \& Pardo, M. (2014). Flat versus normal subduction zones: a comparison based on 3-D regional traveltime tomography and petrological modelling of central Chile and western Argentina $\left(29^{\circ}-35^{\circ} \mathrm{S}\right)$. Geophysical Journal International, 199(3), 1633-1654. 
604

605

606

607

608

609

610

611

612

613

614

615

616

617

618

619

620

621

622

623

624

625

626

627

628

629

630

631

McQuarrie, N., Ehlers, T. A. (2015). Influence of thrust belt geometry and shortening rate on thermochronometer cooling ages: Insights from thermokinematic and erosion modeling of the Bhutan Himalaya. Tectonics, 34(6), 1055-1079.

Nassif, F. S., Canelo, H., Davila, F., \& Ezpeleta, M. (2019). Constraining erosion rates in thrust belts: Insights from kinematic modeling of the Argentine Precordillera, Jachal section. Tectonophysics, 758, 1-11.

Nassif, F; Barrea, A; Davila, F; Mora; A. (2020). Fetkin-hydro, a new thermo-hydrological algorithm for low-temperature thermochronological modeling. Geoscience Frontiers, in press.

Olivetti, V., Balestrieri M., Faccenna C., Fin M. Stuart. (2017) Dating the topography through thermochronology: application of Pecube code to inverted vertical profile in the eastern Sila Massif, southern Italy. Italian Journal of Geosciences 136, no. 3: 321-336.

Pérez M. A., D. Graneros, V. Bagur Delpiano, M. Lauría y K. Breier, (2011). "Exploración de frontera: del modelo superficial a la perforación profunda. Áreas exploratorias Jáchal y Niquivil en la Precordillera de San Juan, Argentina".

Ramos, V. A., Jordan, T. E., Allmendinger, R. W., Mpodozis, C., Kay, S. M., Cortés, J. M., \& Palma, M. (1986). Paleozoic terranes of the central Argentine-Chilean Andes. Tectonics, 5(6), 855-880.

Ramos, V. A. (2004). Cuyania, an exotic block to Gondwana: review of a historical success and the present problems. Gondwana Research, 7(4), 1009-1026.

Ramos VA, Folguera A (2009). Andean flat slab subduction through time. In: Murphy, B. (ed.), Ancient Orogens and Modern Analogues. London, the Geological Society, Special Publication 327: 31-54

Reiners, P. W., \& Ehlers, T. A. (Eds.). (2005). Low-Temperature Thermochronology: Techniques, Interpretations, and Applications (Vol. 58). Walter de Gruyter GmbH \& Co KG.

Richardson, T., Ridgway, K.D., Gilbert, H., Martino, R., Enkelmann, E., Anderson, M., Alvarado, P., (2013). Neogene and Quaternary tectonics of the Eastern Sierras Pampeanas, Argentina: Active intraplate deformation inboard of flat-slab subduction. Tectonics 32, 780-796.

Ring, U., Brandon, M. T., Willett, S. D., \& Lister, G. S. (1999). Exhumation processes. Geological Society, London, Special Publications, 154(1), 1-27. 
632

633

634

635

636

637

638

639

640

641

642

643

644

645

646

647

648

649

650

651

652

653

654

655

656

657

658

659

Sachse, V. F., Strozyk, F., Anka, Z., Rodriguez, J. F., \& Di Primio, R. (2016). The tectono-stratigraphic evolution of the Austral Basin and adjacent areas against the background of Andean tectonics, southern Argentina, South America. Basin Research, 28(4), 462-482.

Sambridge, M., (1999) Geophysical Inversion with a Neighbourhood Algorithm II: appraising the ensemble, Geophys. J. Int., 138, 727-746.

Sánchez, M.A., García, H.P., Acosta, G., Gianni, G.M., Gonzalez, M.A., Ariza, J.P., Martinez, M.P. and Folguera, A., (2019). Thermal and lithospheric structure of the Chilean-Pampean flat-slab from gravity and magnetic data. In Andean Tectonics (pp. 487-507). Elsevier.

Schildgen, T. F., Ehlers, T. A., Whipp Jr, D. M., van Soest, M. C., Whipple, K. X., \& Hodges, K. V. (2009). Quantifying canyon incision and Andean Plateau surface uplift, southwest Peru: A thermochronometer and numerical modeling approach. Journal of Geophysical Research: Earth Surface, 114(F4).

Środoń, J., Morgan, D. J., Eslinger, E. V., Eberl, D. D., \& Karlinger, M. R. (1986). Chemistry of illite/smectite and end-member illite. Clays and Clay Minerals, 34(4), 368-378.

Val, P., Hoke, G. D., Fosdick, J. C., \& Wittmann, H. (2016). Reconciling tectonic shortening sedimentation and spatial patterns of erosion from 10 Be paleo-erosion rates in the Argentine Precordillera. Earth and Planetary Science Letters, 450, 173-185

Valla, P. G., Herman, F., Van Der Beek, P. A., \& Braun, J. (2010). Inversion of thermochronological age-elevation profiles to extract independent estimates of denudation and relief history-l: Theory and conceptual model. Earth and Planetary Science Letters, 295(3-4), 511-522.

Velde, B., \& Vasseur, G. (1992). Estimation of the diagenetic smectite to illite transformation in time-temperature space. American Mineralogist, 77(9-10), 967-976

Vitorello, I., and Pollack H.N., (1980). "On the variation of continental heat flow with age and the thermal evolution of continents." Journal of Geophysical Research: Solid Earth 85.B2: 983-99

Walcek, A. A., \& Hoke, G. D. (2012). Surface uplift and erosion of the southernmost Argentine Precordillera. Geomorphology, 153, 156-168.

Wolf, R. A., Farley, K. A., \& Kass, D. M. (1998). Modeling of the temperature sensitivity of the apatite (U-Th)/He thermochronometer. Chemical Geology, 148(1-2), 105-114. 
660 Zapata, T. R., \& Allmendinger, R. W. (1996). Growth stratal records of instantaneous and 661 progressive limb rotation in the Precordillera thrust belt and Bermejo basin, Argentina. Tectonics, 662 15(5), 1065-1083.

663 Zapata, S., Sobel, E. R., Del Papa, C., \& Glodny, J. (2020). Upper Plate Controls on the Formation of 664 Broken Foreland Basins in the Andean Retroarc Between $26^{\circ} \mathrm{S}$ and $28^{\circ} \mathrm{S}$ : From Cretaceous Rifting 665 to Paleogene and Miocene Broken Foreland Basins. Geochemistry, Geophysics, Geosystems, 21(7) 666 667 


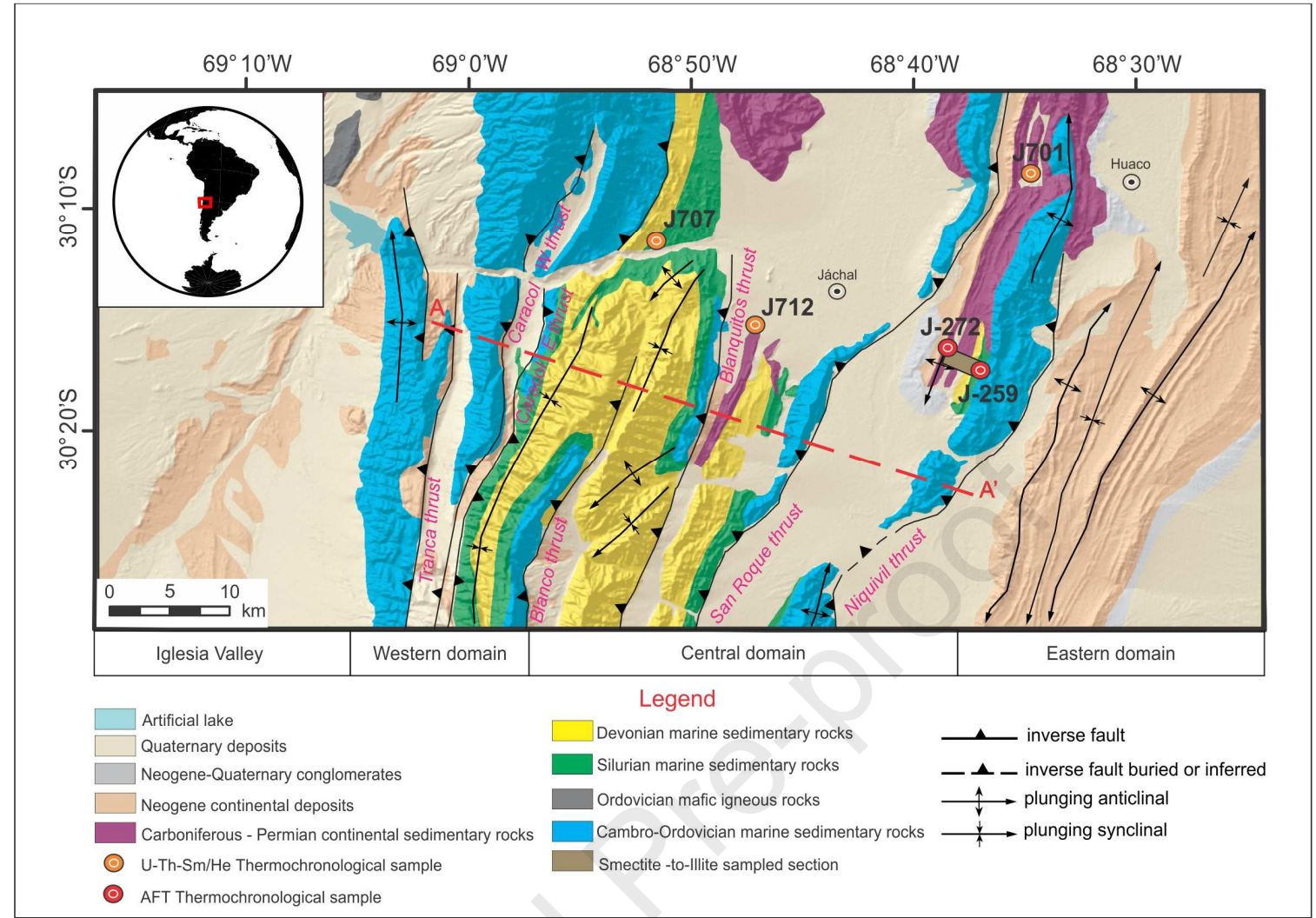

669 Fig 1. Geological-structural map of the study area (Jachal-Rodeo section after Nassif et al., 2019.

670 Geological characterization after Allmendinger and Judge, 2014). U-Th/He thermochronological 671 samples J701, J707 and J712 after Fosdick et al. (2015) and J272 and J259 are our own AFT 672 samples. 

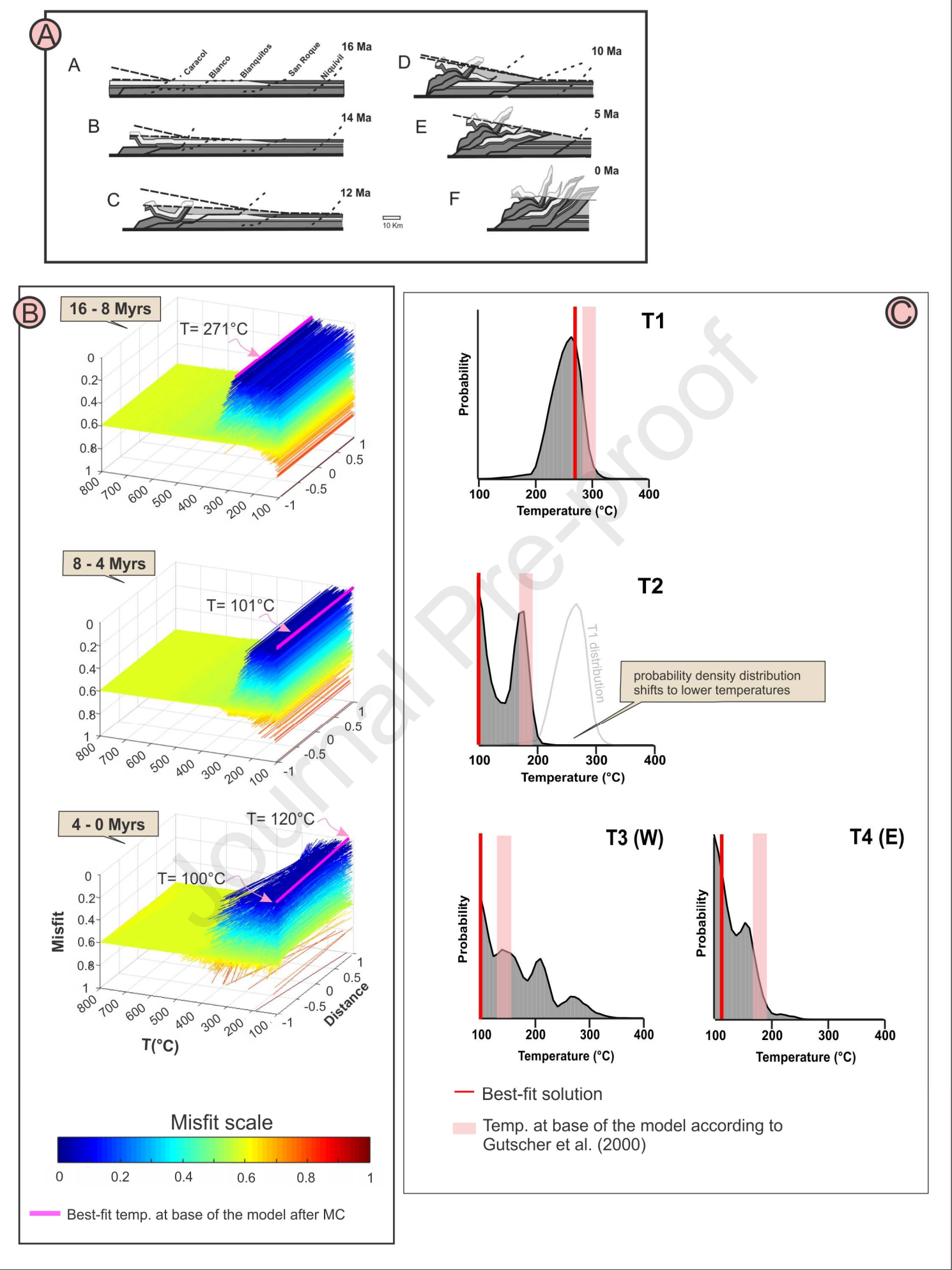

8 - 4 Myrs
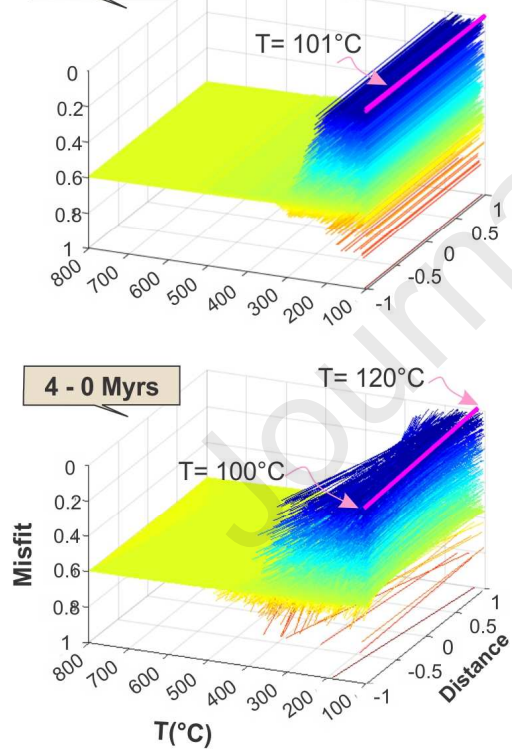

Misfit scale

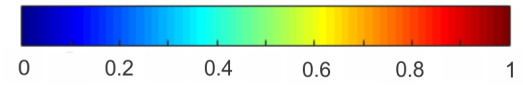

Best-fit temp. at base of the model after MC

675 Fig 2. Monte Carlo sampling results. A) Kinematics considered after Nassif et al. (2019); B) Thermal 676 candidates for each of the three periods considered displayed with their respective normalized 
677 misfit value (see color scale); C) 1D marginal probability distributions for the four parameters 678 calculated with the approach of Sambridge (1999). The red lines mark values for the best model 679 obtained from the MC sampling (the model with the minimum misfit over all 4 parameters). 680 Estimates of temperatures at the base of the model $(20 \mathrm{Km})$, after numerical subduction models of 681 Gutscher et al (2000), are also shown (see pink rectangles)

682

683 

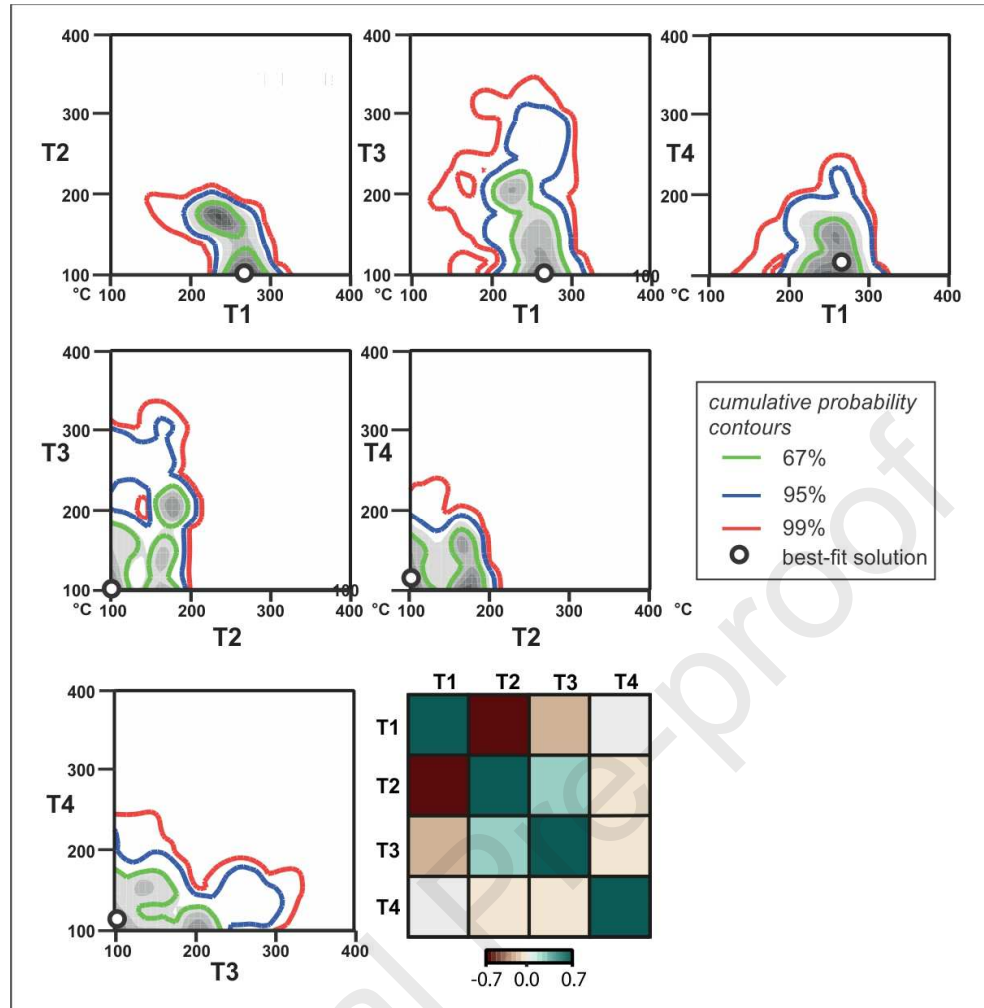

686 Fig. 3. 2D marginal probability distributions for the 6 combinations of the 4 temperature 687 parameters. The green, blue and red contours indicate 67, 95 and 99\% probability and the white 688 circles indicate the values for the best model obtained from the MC sampling (the model with the 689 minimum misfit over all 4 parameters). The lower right panel illustrates the correlation matrix for 690 the 4 parameters, with each square indexed by the parameter values on the top and the left of the 691 image. The green colours indicate a positive correlation, brown colours a negative correlation and 692 the lighter the colour, the closer to zero the correlation coefficient (i.e. low correlation). All 693 parameters are perfectly correlated with themselves, so the diagonal (dark green) $=1$. 


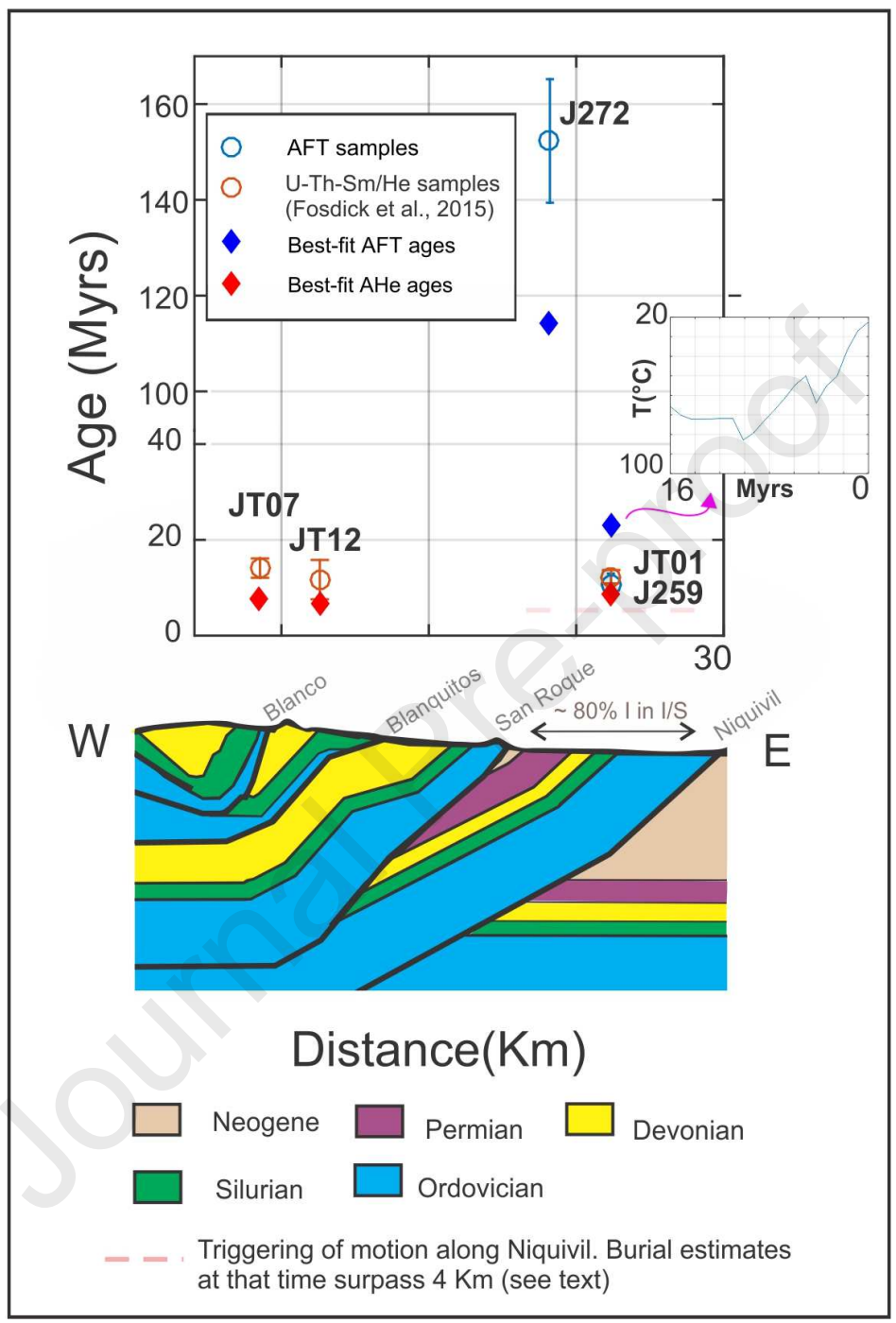

698 Fig 4. Forward modeled thermochronological ages. Interpreted present-day structural section of 699 Jachal AP (Nassif et al., 2019) and measured \%l in mixed I/S (this work), are also shown. U-Th$700 \mathrm{Sm} / \mathrm{He}$ ages after Fosdick et al. (2015) 
(A)

Sample J272
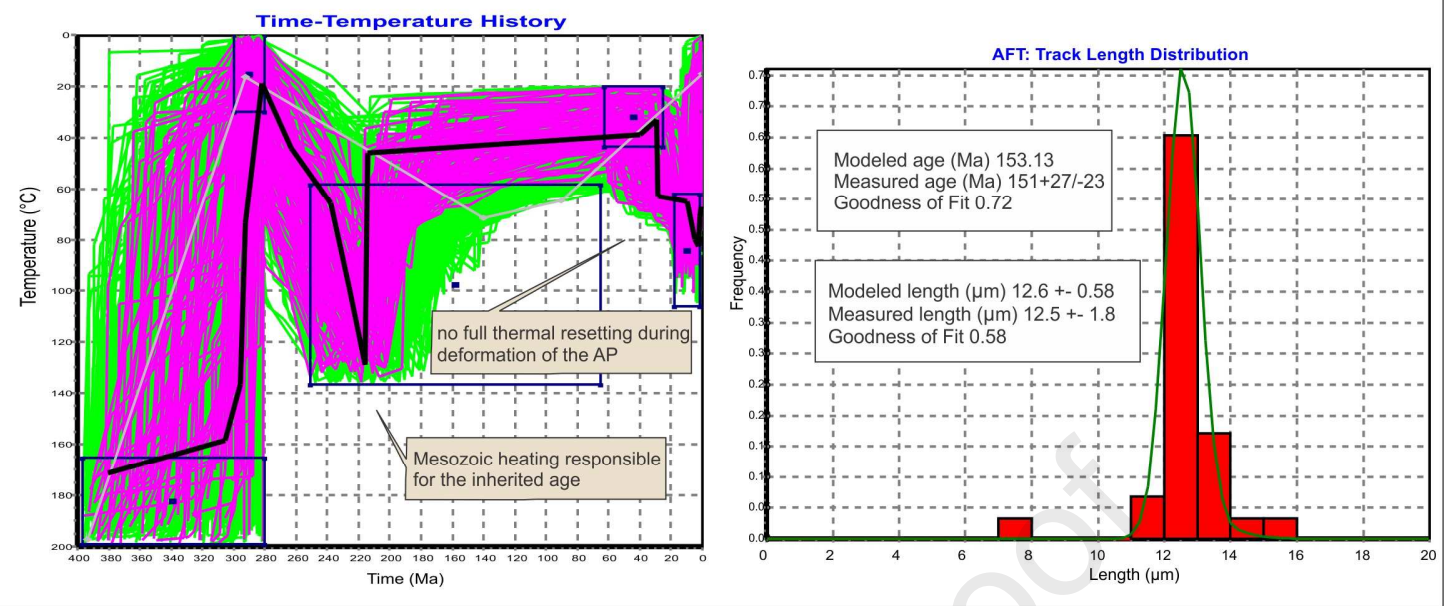

(B) Sample J259
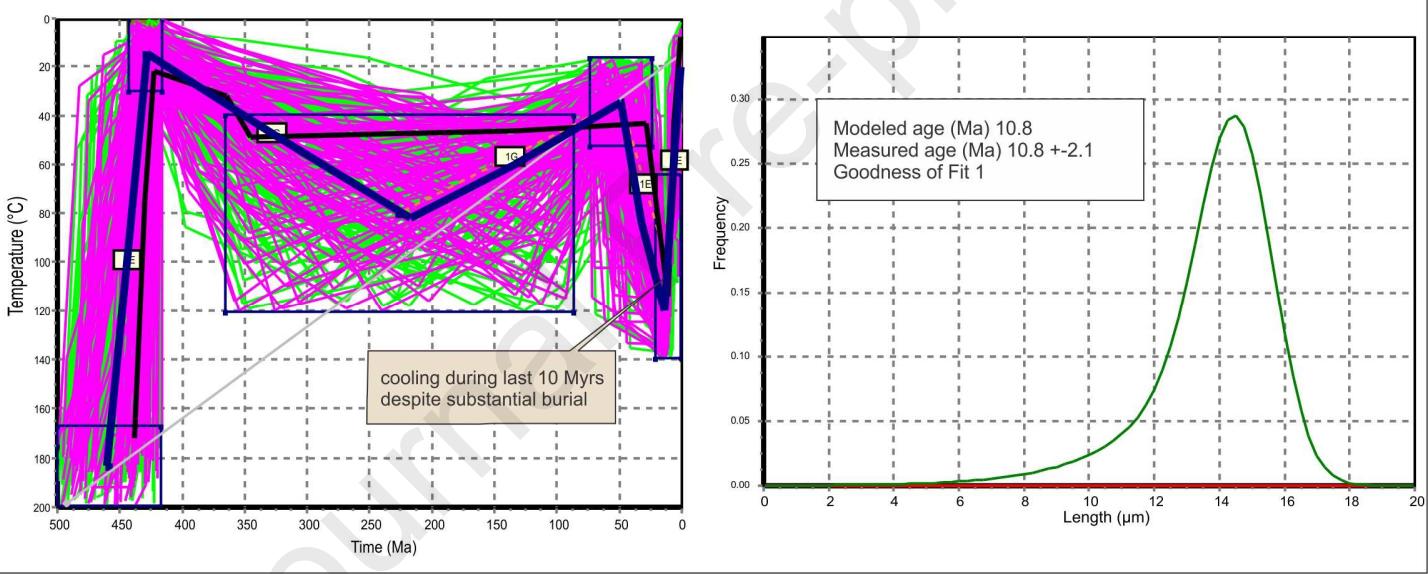

Fig. 5. Inverted time-temperature histories and track length distributions of samples $\mathrm{J} 272$ and 


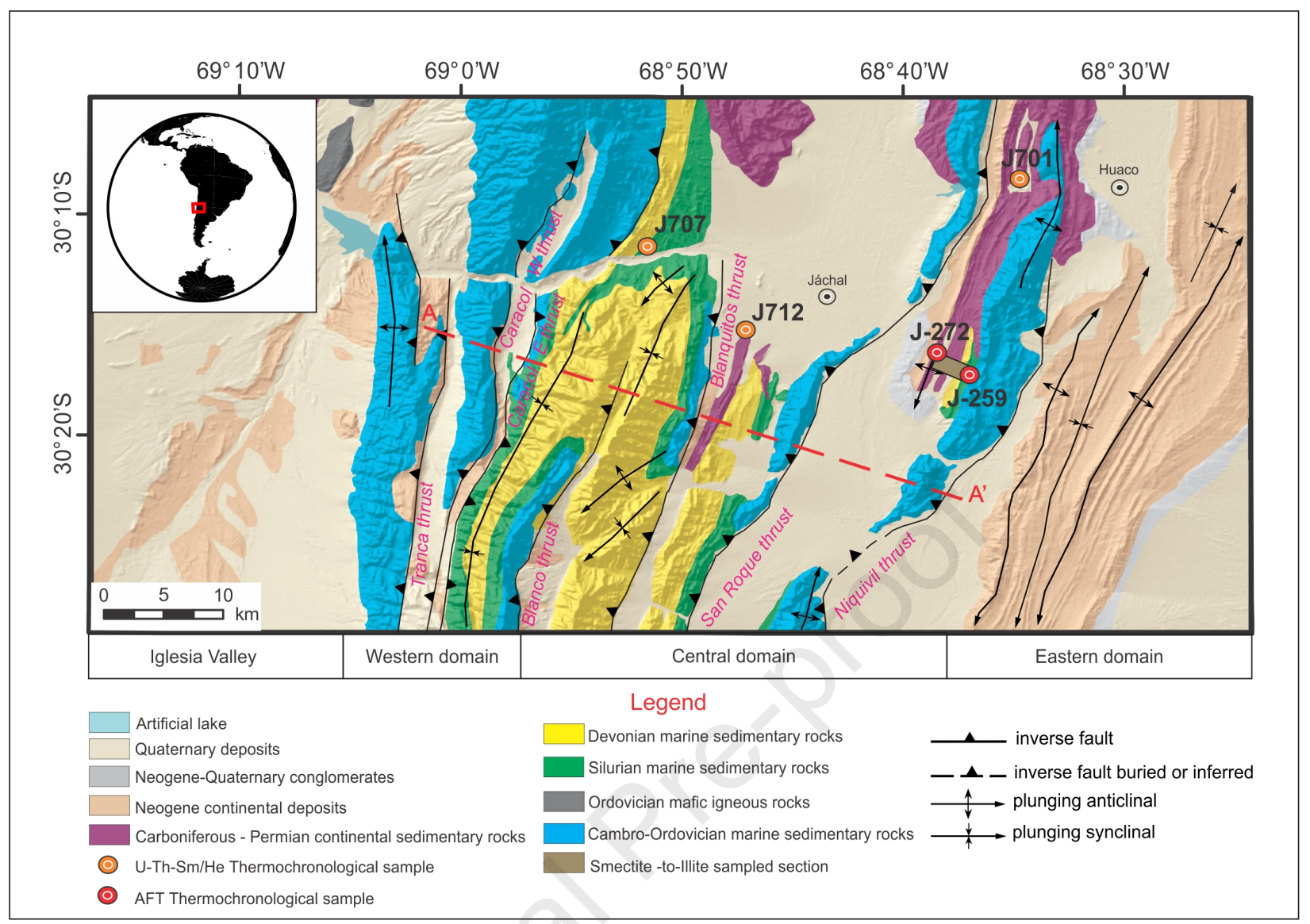




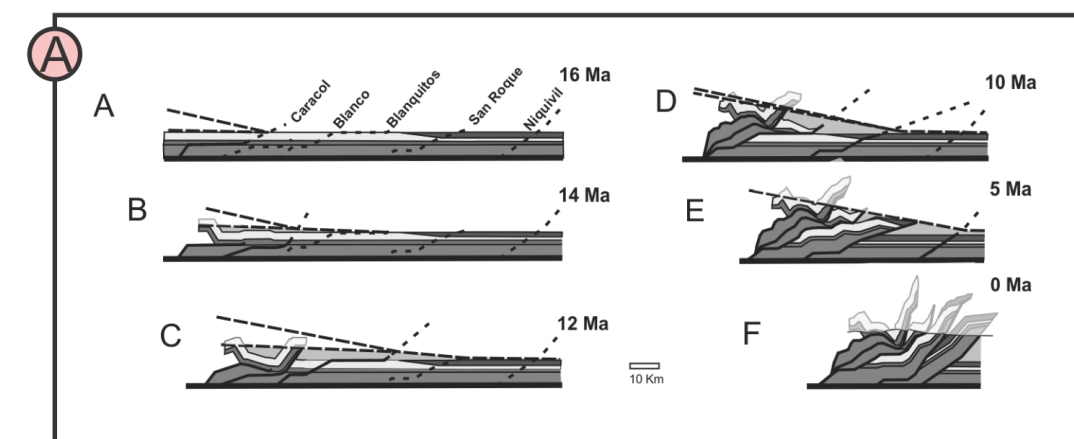

(B)

\section{6 - 8 Myrs}

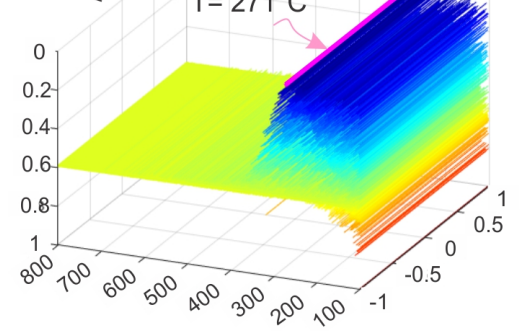

8 - 4 Myrs
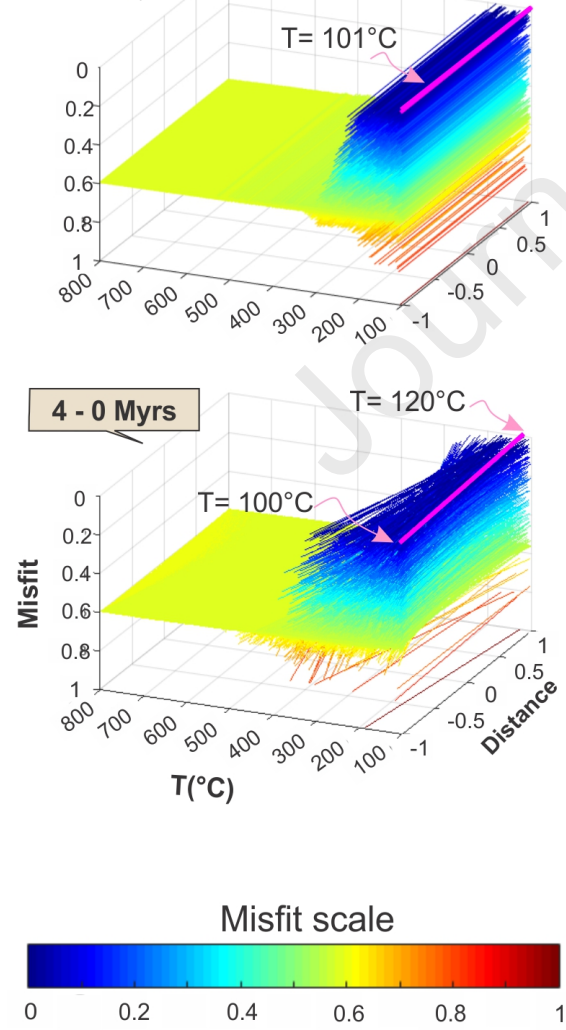

Best-fit temp. at base of the model after MC

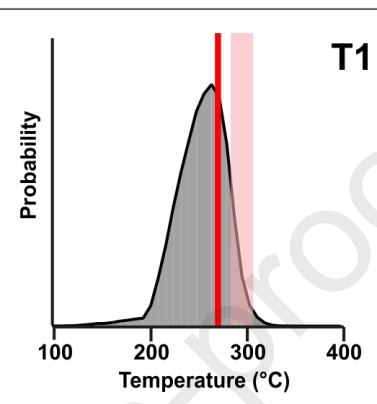

(C)
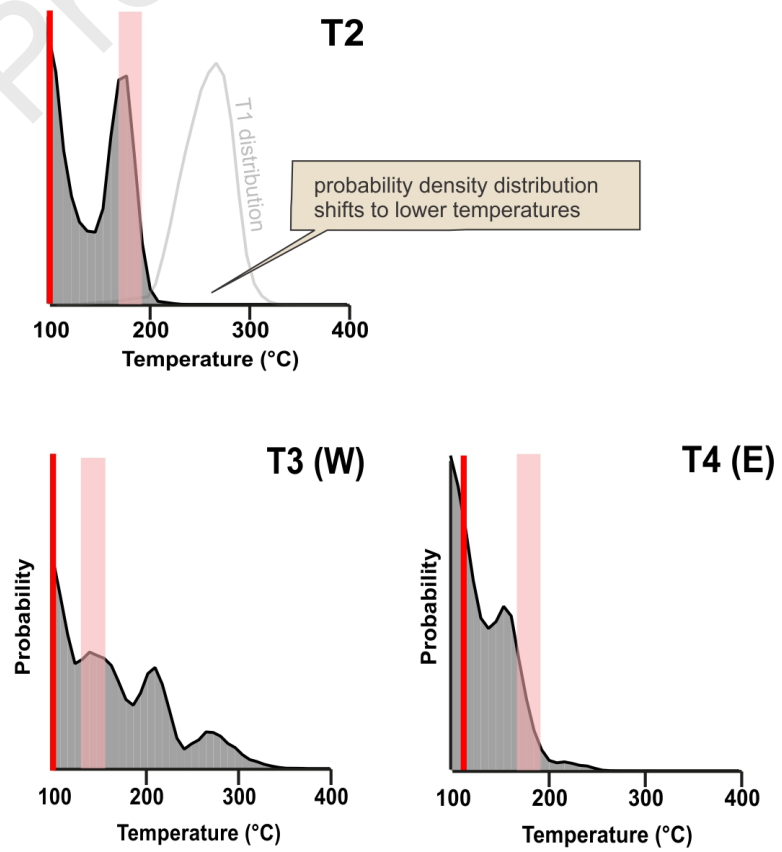

- Best-fit solution

Temp. at base of the model according to Gutscher et al. (2000) 


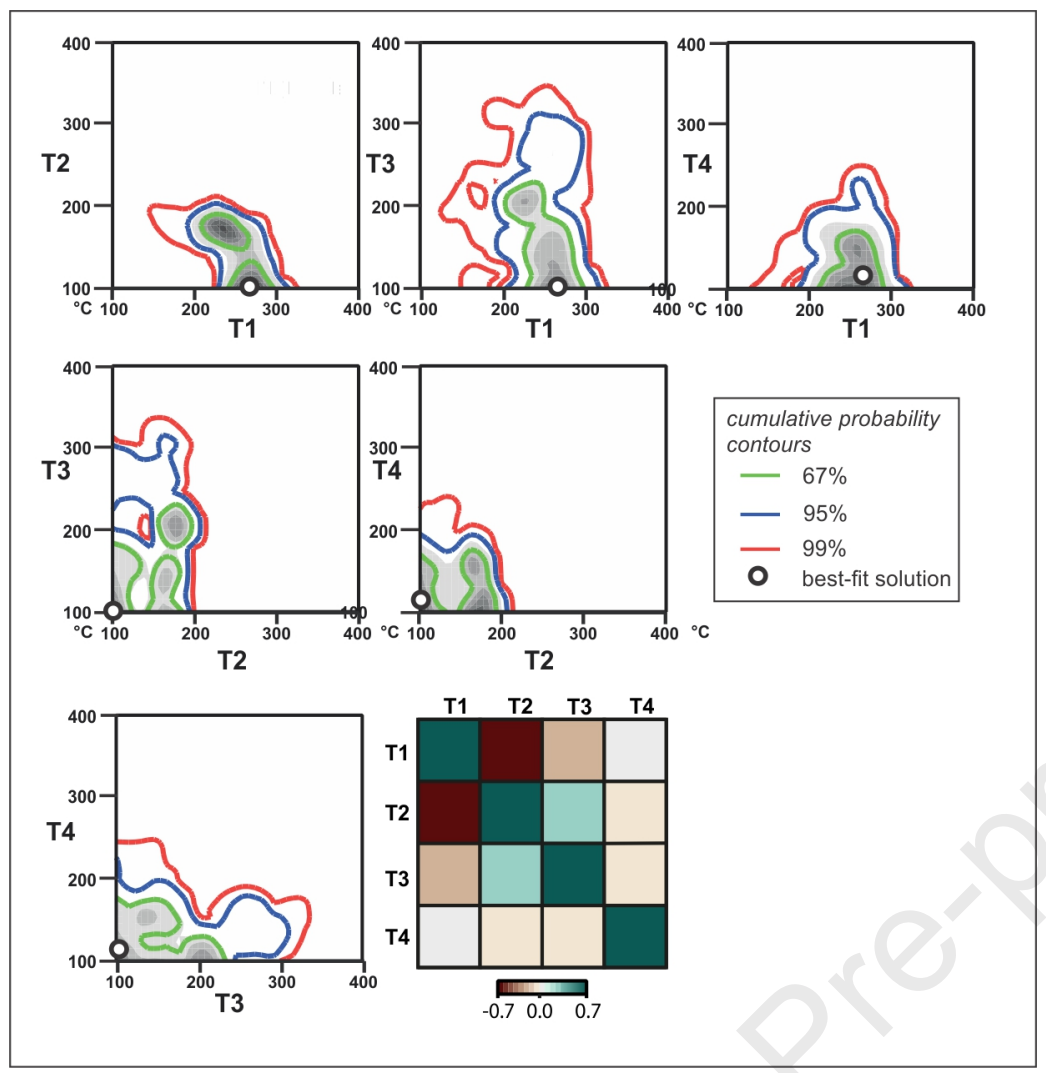




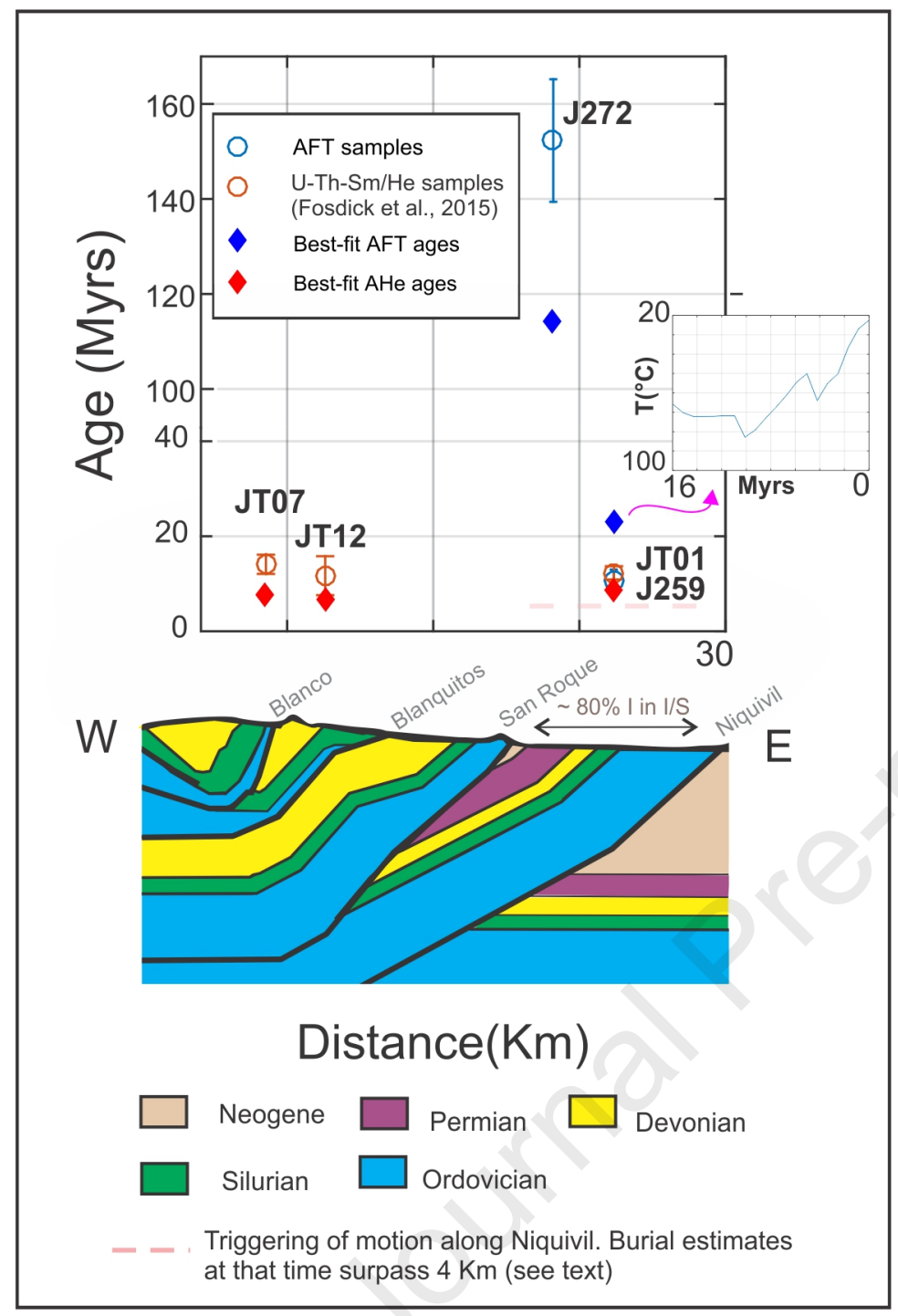


(A) Sample J272
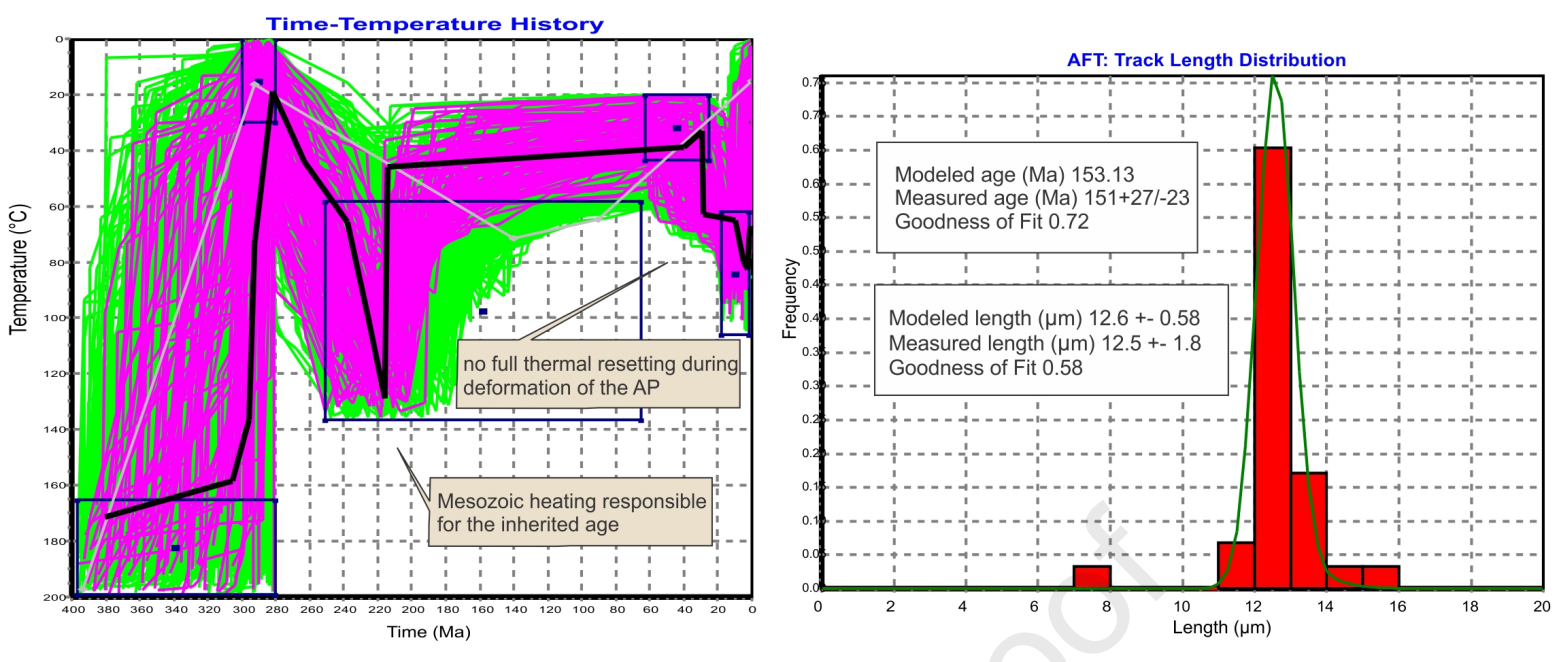

(B) Sample J259
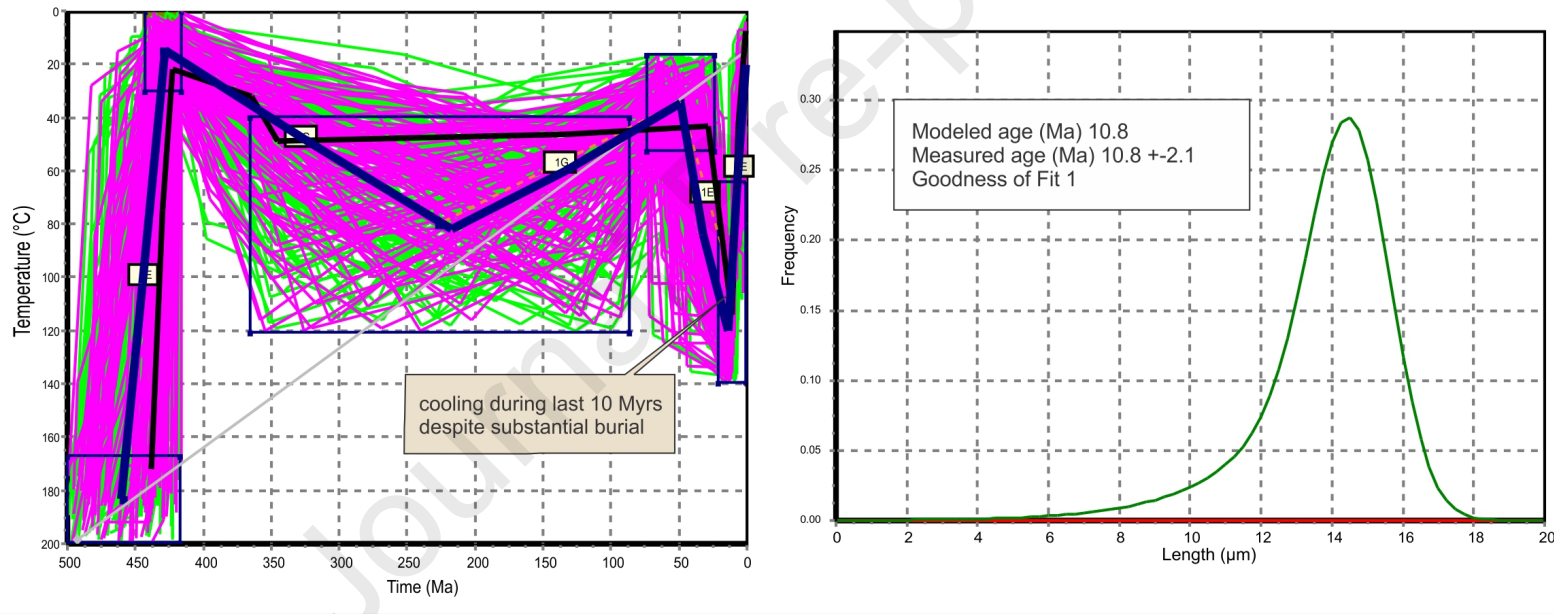
- Low-temperature thermochronological data are used to estimate unsteady basal boundary conditions in 2D thermokinematic simulations

- Geodynamic signals from deep Earth processes are linked to shallow-crust thermochronological signals by means of Monte Carlo sampling

- Inversion of transient boundary conditions discloses effects of flat slab subduction in the Argentine Precordillera 


\section{Declaration of interests}

$\bigotimes$ The authors declare that they have no known competing financial interests or personal relationships that could have appeared to influence the work reported in this paper.

$\square$ The authors declare the following financial interests/personal relationships which may be considered as potential competing interests: 